\title{
Neuroblastoma xenograft models demonstrate the therapeutic potential of 177 Lu-octreotate
}

\author{
Arman Romiani ${ }^{1,2^{*}}$, Johan Spetz ${ }^{1}$, Emman Shubbar ${ }^{1}$, Dan E. Lind ${ }^{3}$, Bengt Hallberg ${ }^{3}$, Ruth H. Palmer ${ }^{3}$ and \\ Eva Forssell-Aronsson ${ }^{1,4}$
}

\begin{abstract}
Background: Neuroblastoma (NB) is one of the most frequently diagnosed tumors in infants. NB is a neuroendocrine tumor type with various characteristics and features, and with diverse outcome. The most malignant NBs have a 5-year survival rate of only $40-50 \%$, indicating the need for novel and improved treatment options. ${ }^{177}$ Lu-octreotate is routinely administered for treatment of neuroendocrine tumors overexpressing somatostatin receptors (SSTR). The aim of this study was to examine the biodistribution of ${ }^{177} \mathrm{Lu}$-octreotate in mice bearing aggressive human NB cell lines, in order to evaluate the potential usefulness of ${ }^{177}$ Lu-octreotate for treatment of NB.

Methods: BALB/c nude mice bearing CLB-BAR, CLB-GE or IMR-32 tumor xenografts ( $n=5-7 /$ group) were i.v. injected with $0.15 \mathrm{MBq}, 1.5 \mathrm{MBq}$ or $15 \mathrm{MBq}{ }^{177}$ Lu-octreotate and sacrificed $1 \mathrm{~h}, 24 \mathrm{~h}, 48 \mathrm{~h}$ and $168 \mathrm{~h}$ after administration. The radioactivity concentration was determined for collected tissue samples, tumor-to-normal-tissue activity concentration ratios (T/N) and mean absorbed dose for each tissue were calculated. Immunohistochemical (IHC) staining for SSTR1-5, and Ki67 were carried out for tumor xenografts from the three cell lines.

Results: High ${ }^{177} \mathrm{Lu}$ concentration levels and T/N values were observed in all NB tumors, with the highest for CLBGE tumor xenografts (72\%lA/g $24 \mathrm{~h}$ p.i.; $1.5 \mathrm{MBq}{ }^{177} \mathrm{Lu}$-octreotate). The mean absorbed dose to the tumor was 6.8 Gy, 54 Gy and 29 Gy for CLB-BAR, CLB-GE and IMR-32, respectively, p.i. of $15 \mathrm{MBq}{ }^{177}$ Lu-octreotate. Receptor saturation was clearly observed in CLB-BAR, resulting in higher concentration levels in the tumor when lower activity levels where administered. IHC staining demonstrated highest expression of SSTR2 in CLB-GE, followed by CLB-BAR and IMR-32.

Conclusion: T/N values for all three human NB tumor xenograft types investigated were high relative to previously investigated neuroendocrine tumor types. The results indicate a clear potential of ${ }^{177}$ Lu-octreotate as a therapeutic alternative for metastatic NB.
\end{abstract}

Keywords: Neuroendocrine tumor, Peptide receptor radionuclide therapy, Somatostatin receptors, ${ }^{177}$ Lu-DOTATATE, Lutathera

\footnotetext{
* Correspondence: arman.romiani@gu.se

'Department of Medical Radiation Sciences, Institute of Clinical Sciences,

Sahlgrenska Center for Cancer Research, Sahlgrenska Academy, University of Gothenburg, Gothenburg, Sweden

2Department of Medical Physics, Sahlgrenska University Hospital, SE-41345

Gothenburg, Sweden

Full list of author information is available at the end of the article
}

(c) The Author(s). 2021 Open Access This article is licensed under a Creative Commons Attribution 4.0 International License, which permits use, sharing, adaptation, distribution and reproduction in any medium or format, as long as you give appropriate credit to the original author(s) and the source, provide a link to the Creative Commons licence, and indicate if changes were made. The images or other third party material in this article are included in the article's Creative Commons licence, unless indicated otherwise in a credit line to the material. If material is not included in the article's Creative Commons licence and your intended use is not permitted by statutory regulation or exceeds the permitted use, you will need to obtain permission directly from the copyright holder. To view a copy of this licence, visit http://creativecommons.org/licenses/by/4.0/ The Creative Commons Public Domain Dedication waiver (http://creativecommons.org/publicdomain/zero/1.0/) applies to the data made available in this article, unless otherwise stated in a credit line to the data. 


\section{Introduction}

Neuroblastoma (NB) represents 7-9\% of all tumors detected in children $[1,2]$. NB are neuroendocrine tumors (NETs), deriving from primitive nerve cells in the sympathetic nervous system. Approximately two thirds of the patients develop tumor in the abdominal region with the adrenal glands being the primary organ [1], although it can also originate from the thorax, pelvis, spine or neck. Metastatic disease is present in more than $50 \%$ of patients, with metastases most commonly located in regional lymph nodes, bone marrow, bone, liver, and skin [3]. NB is a heterogeneous cancer type with various characteristics and features, and with diverse outcomes. Patients with NB are divided into different riskassessment groups, and The International Neuroblastoma Risk Group (INRG) applies a classification system based on key NB criteria, such as age, stage, tumor histology, MYCN amplification (MNA), 11q deletion and ploidy to define very low-, low-, intermediate-, and highrisk (HR) groups according to 5-year event-free survival (EFS) [4]. Patients with HR-NB have a 5-year survival rate of only $40-50 \%$, as compared to $90-100 \%$ for those with low-risk NB $[5,6]$. HR-NB harbors genetic aberrations such as deletion of chromosome arm 1p, 17q-gain, amplification of MYCN and deletion of parts of chromosome 11q. Two NB groups are considered as HR, the MYCN amplified (29-25\%) and the 11q-deletions (35$45 \%)$ groups [7]. Surgery alone leads to a good prognosis for patients with resectable low-risk NB. For patients with HR-NB, multimodal therapy including targeted therapy, surgery, chemotherapy, radiation therapy and autologous peripheral blood stem cell transplantation (ASCT) are included [8]. In cases of disseminated disease systemic treatments are needed.

Diagnosis and therapy using the norepinephrine analogue metaiodobenzylguanidine (MIBG) is an already established radiopharmaceutical option for patients with NB. ${ }^{131}$ I-MIBG therapy have response rates of $20-37 \%$ in patients with refractory and relapsed NB [9, 10]. Treatments with doxorubicin in combination with surgery or inhibitors such as ixazomib have proven antitumor effects in preclinical studies [11, 12]. Further chemotherapy regimens that have been suggested for HR-NB, due to a randomized phase- 3 trial, is busulfan in combination with melphalan [13]. The combination of topotecan, cyclophosphamide, and etoposide have also demonstrated promising results for relapsed and untreated NB in a phase-II trial [14]. Dinutuximab is an antiGD2 monoclonal antibody which is both EMA- and FDAapproved for first line treatment of HR-NB. Immunotherapy with dinutuximab in combination with granulocytemacrophage colony-stimulating factor, interleukin-2 and isotretinoin was compared to treatment with isotretinoin for HR-NB patients and resulted to a 2-year EFS of 66 and
$46 \%$, respectively [15]. By observing survival rates over the past decades, it is clear that the treatment methods for NB patients have improved. However, survival rates for HR-NB remain low [5], which strengthens the need for more effective treatment methods.

Systemic radionuclide therapy with ${ }^{177} \mathrm{Lu}$-octreotate could be a potential treatment option for HR-NB. NETs often overexpress somatostatin (SS) receptors (SSTRs), which enables the use of radiolabeled SS analogues for diagnostics and therapy of SSTR-expressing NETs. There are five different subtypes of SSTRs, SSTR1-5. All but SSTR1 are internalized into the cell after binding with an appropriate agonist [16]. Previous studies demonstrate the expression of SSTRs in NBs, most prominently SSTR1 and SSTR2 [17-21]. Prominent proliferation and MIBG-avidity in NBs are factors that seems to correlate with high SSTR2 expression [19, 22]. Octreotate is an SS analogue, with highest affinity towards SSTR2 and somewhat lower to SSTR4 and SSTR5 [23]. Today, radionuclide therapy using ${ }^{177} \mathrm{Lu}$-octreotate is an EMA and FDA approved treatment option for patients with gastroenteropancreatic NETs. ${ }^{177}$ Lu-octreotate has recently been included in a phase II study for patients with relapsed or refractory metastatic HR-NB with modest results [24]. Reviewing the treatment schedule and optimizing the amount of activity administered were factors that could have impacted the results. The benefits of a personalized approach are seen in a study where a refractory metastatic HR-NB-patient received an adapted ${ }^{177} \mathrm{Lu}$-octreotate treatment which prevented the tumor progression [25].

Today, there is a lack of knowledge in how ${ }^{177} \mathrm{Lu}$-octreotate is distributed in NB patients. In our previous in vitro studies, the binding and internalization of ${ }^{177} \mathrm{Lu}$-octreotate to the two NB cell lines IMR-32 and CLB-BAR were investigated (Binding and internalization of ${ }^{177} \mathrm{Lu}$-octreotate in cell lines of neuroblastoma, breast cancer, and non-small cell lung cancer, submitted). The results indicated a high specific binding and internalization of ${ }^{177} \mathrm{Lu}$-octreotate for both cell lines. These promising results encouraged us to study this further in human NB xenograft models.

This paper explores the biodistribution of ${ }^{177} \mathrm{Lu}-$ octreotate in NB xenograft bearing nude mice and evaluates the potential of ${ }^{177} \mathrm{Lu}$-octreotate as a treatment option for patients with NB. The study was performed on three human NB xenograft animal models. To our knowledge this is the first biodistribution study of ${ }^{177} \mathrm{Lu}$ octreotate in mice bearing human NB xenografts.

\section{Methods}

\section{Experimental study}

Female nude BALB/c mice (Janvier Labs, France and Charles River Laboratories, Inc., UK) aged 5-6 weeks $(n=5-7)$ were s.c. inoculated with $2 \times 10^{6} \mathrm{NB}$ cells on the flank. Three NB cell lines were employed in this 
study: CLB-BAR, a MYCN/ALK amplified cell line with a constitutively active ALK due to a deletion of ex4-11 in the $A L K$ locus [26, 27]; CLB-GE that harbors both $M Y C N$ and $A L K$ amplifications as well as a gain-offunction $A L K^{F 1174 V}$ mutation [28]; and IMR-32, a $M Y C N$-amplified cell line with no $A L K$ mutation, but with amplification of exon 3 and 4 of $A L K$ together with $1 \mathrm{p}$ deletion and $17 \mathrm{q}$ gain [28-32]. CLB-BAR and CLBGE are from Centre Leon Berard, France, under MTA. NB cells were cultured in complete media, RPMI 1640 supplemented with $10 \%$ fetal bovine serum (FBS) and a mixture of $1 \%$ penicillin/streptomycin at $37{ }^{\circ} \mathrm{C}$ and $5 \%$ $\mathrm{CO}_{2}$.

${ }^{177} \mathrm{Lu}$-octreotate $\left[{ }^{177} \mathrm{Lu}\right.$-DOTA $\left.{ }^{0}, \mathrm{Tyr}^{3}\right]$-octreotate was prepared according to the manufacturer's instructions (Mallinckrodt Medical BV, NRG, Petten, Netherlands). The radiochemical purity was above $98 \%$ in all studies, determined by instant thin layer chromatography SilicaGel (ITLC-SG) technique (chromatography paper 50/ PK, Varian, USA).

After approximately 5-8 weeks, dependent on the cell line, the tumor volume was greater than $250 \mathrm{~mm}^{3}$ and the animal was included in the study. The volume of the tumor was estimated assuming the volume of an ellipsoid: $V=\frac{4 \pi \cdot a \cdot b \cdot c}{3}$, where $\mathrm{a}, \mathrm{b}$ and $\mathrm{c}$ are the three perpendicular axes of the tumor, measured by a digital caliper. The mice were i.v. injected with $0.15,1.5$ or $15 \mathrm{MBq}$ ${ }^{177} \mathrm{Lu}$-octreotate, always in $0.15 \mathrm{ml}$ saline solution. The ${ }^{177} \mathrm{Lu}$ activity in each syringe was measured in an ionization chamber (CRC-15R, Capintec, Inc., New Jersey, USA) before and after injection to determine the administered activity to each mouse. The mice were sacrificed $1 \mathrm{~h}, 24 \mathrm{~h}, 48 \mathrm{~h}$ or $168 \mathrm{~h}$ after administration ( $n=5-6$ per group) by cardiac puncture during anesthesia with pentobarbitalnatrium vet. $(60 \mathrm{mg} / \mathrm{ml}$, Apotek Produktion \& Laboratorier AB, Sweden) injected intraperitoneally. Thereafter, adrenals, blood sample, brain, kidneys, liver, lungs, spleen and tumor were collected and weighed. Tumor samples were divided into two parts, one for ${ }^{177} \mathrm{Lu}$ activity measurement and one for immunihistochemical examination. All animal experiments were approved by the Ethical Committee on Animal Experiments in Gothenburg, Sweden (reference number: 107-15) on behalf of the Swedish National Committee for the Protection of Animals used for Scientific Purposes. The study was conducted in accordance with guidelines from Animal Research: Reporting of In Vivo Experiments (ARRIVE) and all methods were carried out in accordance with relevant guidelines and regulations.

The ${ }^{177} \mathrm{Lu}$ activity in tissue sample, $\mathrm{A}_{\text {tissue }}(\mathrm{t})$, was measured by a Wallac $1480 \mathrm{NaI}$ (Tl) gamma counter (Wizard 3, serial no. 480036) using a $20 \%$ energy window centered around $208 \mathrm{keV}$. The gamma counter was calibrated against the ionization chamber and all measurement results were corrected for dead time and background radiation levels. The radioactivity concentration in each tissue sample, $C_{\text {tissue }}(t)$, was determined as percent of injected ${ }^{177} \mathrm{Lu}$ activity per mass of tissue (\%IA/g).

$$
C_{\text {tissue }}(t)=\frac{A_{\text {tissue }}(t)}{m_{\text {tissue }} \times A_{\text {injected }}(t)} \times 100 \%,
$$

Tumor-to-normal-tissue ${ }^{177} \mathrm{Lu}$ activity concentration ratios $(\mathrm{T} / \mathrm{N})$ were determined

$$
\frac{T}{N}(t)=\frac{C_{\text {tumor }}(t)}{C_{\text {normal_tissue }}:(t)}
$$

\section{Dosimetry}

The mean absorbed dose in target tissue, $r_{T}$, at time $T_{D}$ after injection, $D\left(r_{T}, T_{D}\right)$, was calculated based on the equation from Medical Internal Radiation Dose (MIRD) Pamphlet No. 21 [33]:

$$
D\left(r_{T}, T_{D}\right)=\frac{\tilde{A}\left(r_{S}, T_{D}\right) \sum_{i} E_{i} Y_{i} \varnothing\left(r_{T} \leftarrow r_{S}, E_{i}, T_{D}\right)}{M\left(r_{T}, T_{D}\right)}
$$

In all calculations the source tissue and the target tissue were considered to be equal. Only beta particles, and Auger- and conversion electrons were included in the calculations and the absorbed fraction, $\varnothing$, was set to 1 . The mean energy of the $\mathrm{i}^{\text {th }}$ transition per nuclear transformation, $\Sigma_{i} E_{i} Y_{i}$, was set to $147.9 \mathrm{keV}$ [34]. Based on the activity concentrations at the various time points studied ( $1 \mathrm{~h}, 24 \mathrm{~h}, 48 \mathrm{~h}$ and $168 \mathrm{~h}$ ) an exponential function was fitted to the data for each tissue. $\tilde{A}$ was determined by calculating the integral of respectively exponential function, and $T_{D}$ was set to $\infty$.

\section{Immunohistochemistry (IHC)}

Tumor samples were fixed in formalin, embedded in paraffin and cut into $4 \mu \mathrm{m}$ sections. The sections were deparaffinized, rehydrated and processed with the Dako EnVision TM FLEX antigen retrieval EDTA buffer $\mathrm{pH} 9$ using DAKO PT Link module (PT Link, Dakocytomation, Denmark) according to the manufacturer's instructions. The sections were then stained with hematoxylin and eosin (H\&E) and thereafter immunohistochemical staining for SSTR1-5 and Ki67 was carried out (FLEX IHC microscope slides, Dako, Sweden). The IHC procedure was performed using DAKO stainer (DAKO Autostainer plus, Dakocytomation, Denmark) following the manufacturer's instructions. The antibodies employed were rabbit anti-SSTR1 (HPA031506, 1:750; Sigma-Aldrich, Stockholm, Sweden), rabbit anti-SSTR2 (ab134152, 1:50; abcam, Cambridge, UK), rabbit antiSSTR3 (PA3-110, 1:250; Thermo Fisher Scientific, 
Gothenburg, Sweden), rabbit anti-SSTR4 (NBP2-39022, 1: 25; Novus Biologicals, Stockholm, Sweden), rabbit anti-SSTR5 (PA3-110, 1:250; Thermo Fisher Scientific) and rabbit antiKi-67 (AB9260, 1:100; Merck Millipore, Stockholm, Sweden). For positive control of SSTR1-5, tissue from human cerebellum was applied for SSTR1 and SSTR3-5, and tissue from human small intestinal NET was applied for SSTR2.

\section{Statistical analyses}

All biodistribution data were given as mean and standard error of mean (SEM). A one-way ANOVA test was performed in order to determine the statistically significant differences between data from the groups. $P$-values $<0.05$ were considered statistically significant.

\section{Results}

In general, high concentration levels of ${ }^{177} \mathrm{Lu}$ were observed in all human NB tumor xenograft tissues investigated (Tables 1, 2 and 3). The adrenal glands, kidneys and lungs reached higher ${ }^{177} \mathrm{Lu}$ activity concentration levels than the other normal organs. Dose- and timedependent differences in the ${ }^{177} \mathrm{Lu}$ concentration levels were observed. A decrease of the ${ }^{177} \mathrm{Lu}$ concentration over time was observed for all tissues, but retention was higher in the tumor tissue compared with that of other organs.

\section{Tumor tissue}

High ${ }^{177} \mathrm{Lu}$ activity concentration levels were observed in CLB-BAR, CLB-GE and IMR-32 NB xenograft tumors (Tables 1, 2 and 3, Figs. 1, 2 and 3), with the highest value (59\%IA/g $1 \mathrm{~h}$ p.i.) observed in mice bearing CLBBAR xenografts after administration of $0.15 \mathrm{MBq}{ }^{177} \mathrm{Lu}-$ octreotate. The ${ }^{177} \mathrm{Lu}$ concentration decreased in xenograft tumor tissues over the $168 \mathrm{~h}$ interval, regardless of the amount injected, for all experiments except for CLBGE tumors, when the mice were injected with $15 \mathrm{MBq}$ ${ }^{177} \mathrm{Lu}$-octreotate. In this case an increase was observed, although this was not statistically significant $(p=0.63)$, from $27 \% \mathrm{IA} / \mathrm{g} 1 \mathrm{~h}$ p.i. to $33 \% \mathrm{IA} / \mathrm{g} 168 \mathrm{~h}$ p.i. (Table 2). When mice bearing CLB-GE xenograft tumors were injected with $0.15 \mathrm{MBq}$ instead, a decrease was observed over a $168 \mathrm{~h}$ interval $(p=0.013)$. For IMR-32 xenograft tumors, the ${ }^{177} \mathrm{Lu}$ concentration levels decreased from displaying a longer retention rate of ${ }^{177} \mathrm{Lu}$-octreotate. In general, lower concentration levels of ${ }^{177} \mathrm{Lu}$ were observed after administration of $15 \mathrm{MBq}{ }^{177} \mathrm{Lu}$-octreotate. The exception, as mentioned above, being the CLB-GE tumors having the highest observed concentration level of ${ }^{177} \mathrm{Lu} 168 \mathrm{~h}$ p.i. with $15 \mathrm{MBq}{ }^{177} \mathrm{Lu}$-octreotate.

\section{Normal tissues}

The kidneys, lungs and adrenal glands were consistently the three normal organs that had the highest

Table 1 Biodistribution of ${ }^{177}$ Lu-octreotate in CLB-BAR-bearing nude mice. Data is given as ${ }^{177}$ Lu activity concentration (\%lA/g) in each tissue and tumor-to-normal-tissue ${ }^{177}$ Lu activity concentration ratios (T/N) at 1, 24, 48 (only for $15 \mathrm{MBq}$ ) and $168 \mathrm{~h}$ post injection of $0.15,1.5$ or $15 \mathrm{MBq}{ }^{177}$ Lu-octreotate $(n=5-6 /$ group). Values are given as mean (SEM)

\begin{tabular}{|c|c|c|c|c|c|c|c|c|c|c|}
\hline \multirow[b]{3}{*}{ Time p.i. } & \multicolumn{10}{|c|}{${ }^{177}$ Lu activity concentration $(\% \mathrm{IA} / \mathrm{g})$} \\
\hline & \multicolumn{3}{|l|}{$0.15 \mathrm{MBq}$} & \multicolumn{3}{|l|}{$1.5 \mathrm{MBq}$} & \multicolumn{4}{|l|}{$15 \mathrm{MBq}$} \\
\hline & $1 \mathrm{~h}$ & $24 \mathrm{~h}$ & $168 \mathrm{~h}$ & $1 \mathrm{~h}$ & $24 \mathrm{~h}$ & $168 \mathrm{~h}$ & $1 \mathrm{~h}$ & $24 \mathrm{~h}$ & $48 \mathrm{~h}$ & $168 \mathrm{~h}$ \\
\hline Adrenals & $17(2)$ & $16(4)$ & $3.3(0.7)$ & $6.6(1.6)$ & $3.4(0.5)$ & $1.0(0.2)$ & $1.8(0.1)$ & $0.16(0.05)$ & $0.077(0.005)$ & $0.26(0.07)$ \\
\hline Blood & $2.0(0.1)$ & $0.51(0.1)$ & $0.18(0.05)$ & $1.5(0.13$ & $0.13(0.04)$ & $0.095(0.05)$ & $0.78(0.11)$ & $0.0053(0.0015)$ & $0.0029(0.0005)$ & $0.009(0.002)$ \\
\hline Brain & $0.35(0.08)$ & $0.29(0.08)$ & $0.058(0.012)$ & $0.28(0.10)$ & $0.074(0.01)$ & $0.027(0.006)$ & $0.22(0.05)$ & $0.0078(0.0008)$ & $0.0074(0.0006)$ & $0.014(0.002)$ \\
\hline Kidneys & $58(6)$ & $25(2)$ & $3.9(0.5)$ & $61(3)$ & $22(1)$ & $2.8(0.2)$ & $57(6)$ & $2.0(0.7)$ & $1.6(0.2)$ & $1.2(0.1)$ \\
\hline Liver & $4.2(0.2)$ & $1.3(0.1)$ & $0.73(0.07)$ & $2.0(0.4)$ & $0.52(0.03)$ & $0.22(0.02)$ & $1.4(0.2)$ & $0.028(0.008)$ & $0.026(0.002)$ & $0.068(0.003)$ \\
\hline Lungs & $54(2)$ & $17(2)$ & $4.1(0.5)$ & $16(2)$ & $4.1(0.9)$ & $1.1(0.1)$ & $3.8(0.4)$ & $0.14(0.03)$ & $0.11(0.00)$ & $0.14(0.01)$ \\
\hline Spleen & $5.7(0.5)$ & $1.5(0.3)$ & $1.5(0.3)$ & $5.1(2.1)$ & $1.1(0.1)$ & $0.65(0.04)$ & $1.1(0.2)$ & $0.052(0.010)$ & $0.054(0.002)$ & $0.13(0.01)$ \\
\hline Tumor & $59(9)$ & $36(3)$ & $13(3)$ & $49(8)$ & $25(1)$ & $4.6(0.6)$ & $14(1)$ & $0.53(0.16)$ & $0.53(0.03)$ & $1.5(0.3)$ \\
\hline \multicolumn{11}{|c|}{ Tumor-to-normal-tissue concentration ratio $(\mathrm{T} / \mathrm{N})$} \\
\hline $\mathrm{T} / \mathrm{N}$ & $1 \mathrm{~h}$ & $24 \mathrm{~h}$ & $168 \mathrm{~h}$ & $1 \mathrm{~h}$ & $24 \mathrm{~h}$ & $168 \mathrm{~h}$ & $1 \mathrm{~h}$ & $24 \mathrm{~h}$ & $48 \mathrm{~h}$ & $168 \mathrm{~h}$ \\
\hline Adrenals & $3.6(0.6)$ & $2.7(1.1)$ & $4.7(1.4)$ & $9.0(2.0)$ & $7.8(0.7)$ & $6.4(1.9)$ & $7.7(0.7)$ & $3.3(0.2)$ & $7.1(0.6)$ & $5.1(1.5)$ \\
\hline Blood & $30(3)$ & $83(17)$ & $96(27)$ & $34(6.0)$ & $270(64)$ & $88(29)$ & $19(2)$ & $101(16)$ & $200(24)$ & $140(37)$ \\
\hline Brain & $200(42)$ & $160(30)$ & $310(96)$ & $240(60)$ & $360(38)$ & $200(40)$ & $71(14)$ & $65(15)$ & $73(6)$ & $73(13)$ \\
\hline Kidneys & $1.1(0.2)$ & $1.4(0.1)$ & $3.3(0.6)$ & $0.81(0.11)$ & $1.2(0.1)$ & $1.6(0.1)$ & $0.25(0.01)$ & $0.67(0.37)$ & $0.34(0.03)$ & $0.97(0.23)$ \\
\hline Liver & $14(2)$ & $27(1)$ & $18(3)$ & $28(5)$ & $50(3)$ & $21(3)$ & $10(1)$ & $22(4)$ & $21(1)$ & $15(3)$ \\
\hline Lungs & $1.1(0.2)$ & $2.2(0.1)$ & $3.4(0.7)$ & $3.0(0.4)$ & $13(7)$ & $4.2(0.6)$ & $3.7(0.4)$ & $3.7(0.8)$ & $4.7(0.2)$ & $6.4(2.3)$ \\
\hline Spleen & $10(1.0)$ & $27(3.9)$ & $12(4)$ & $14(3)$ & $25(3)$ & $7.3(1.1)$ & $14(2)$ & $9.5(1.6)$ & $9.9(0.5)$ & $9.5(3.0)$ \\
\hline
\end{tabular}


Table 2 Biodistribution of ${ }^{177}$ Lu-octreotate in CLB-GE-bearing nude mice. Data is given as ${ }^{177}$ Lu activity concentration (\%IA/g) in each tissue and tumor-to-normal-tissue ${ }^{177}$ Lu activity concentration ratios (T/N) at 1, 24, 48 (only for 15 MBq) and 168 h p.i. with 0.15 or $15 \mathrm{MBq}^{177} \mathrm{Lu}$-octreotate ( $n=5-6 /$ group). Values are given as mean (SEM)

\begin{tabular}{|c|c|c|c|c|c|c|c|}
\hline \multirow[b]{3}{*}{ Time p.i. } & \multicolumn{7}{|c|}{${ }^{177}$ Lu activity concentration $(\% \mid \mathrm{A} / \mathrm{g})$} \\
\hline & \multicolumn{4}{|l|}{$0.15 \mathrm{MBq}$} & \multicolumn{3}{|l|}{$15 \mathrm{MBq}$} \\
\hline & $1 \mathrm{~h}$ & $24 \mathrm{~h}$ & $48 \mathrm{~h}$ & $168 \mathrm{~h}$ & $1 \mathrm{~h}$ & $24 \mathrm{~h}$ & $168 \mathrm{~h}$ \\
\hline Adrenals & $27(7)$ & $14(2)$ & $13(2)$ & $5.2(0.7)$ & $5.5(1.2)$ & $1.5(0.1)$ & $0.63(0.11)$ \\
\hline Blood & $3.1(1.0)$ & $\begin{array}{l}0.35 \\
(0.11)\end{array}$ & $\begin{array}{l}0.16 \\
(0.02)\end{array}$ & $0.11(0.04)$ & $1.5(0.6)$ & $\begin{array}{l}0.044 \\
(0.005)\end{array}$ & $\begin{array}{l}0.014 \\
(0.002)\end{array}$ \\
\hline Brain & $\begin{array}{l}0.33 \\
(0.05)\end{array}$ & $\begin{array}{l}0.19 \\
(0.07)\end{array}$ & $\begin{array}{l}0.17 \\
(0.06)\end{array}$ & $\begin{array}{l}0.045 \\
(0.002)\end{array}$ & $\begin{array}{l}0.33 \\
(0.10)\end{array}$ & $\begin{array}{l}0.084 \\
(0.020)\end{array}$ & $\begin{array}{l}0.019 \\
(0.002)\end{array}$ \\
\hline Kidneys & $59(7)$ & $25(2)$ & $12(2)$ & $1.6(0.2)$ & $37(2)$ & $15(1)$ & $1.2(0.2)$ \\
\hline Liver & $5.7(0.6)$ & $1.2(0.1)$ & $1.2(0.1)$ & $0.60(0.06)$ & $1.3(0.1)$ & $0.42(0.04)$ & $0.11(0.01)$ \\
\hline Lungs & $90(15)$ & $35(3)$ & $27(4)$ & $8.7(1.0)$ & $6.4(0.8)$ & $1.4(0.1)$ & $0.49(0.03)$ \\
\hline Spleen & $8.5(1.2)$ & $2.8(0.1)$ & $2.9(0.4)$ & $1.2(0.1)$ & $1.3(0.2)$ & $0.31(0.02)$ & $0.16(0.01)$ \\
\hline Tumor & $50(14)$ & $34(3)$ & $54(19)$ & $5.0(1.1)$ & $27(7)$ & $12(1)$ & $33(8)$ \\
\hline \multicolumn{8}{|c|}{ Tumor-to-normal-tissue concentration ratio $(\mathrm{T} / \mathrm{N})$} \\
\hline $\mathrm{T} / \mathrm{N}$ & $1 \mathrm{~h}$ & $24 \mathrm{~h}$ & $48 \mathrm{~h}$ & $168 \mathrm{~h}$ & $1 \mathrm{~h}$ & $24 \mathrm{~h}$ & $168 \mathrm{~h}$ \\
\hline Adrenals & $6.7(4.7)$ & $2.7(0.3)$ & $3.8(0.7)$ & $0.96(0.15)$ & $4.7(0.2)$ & $8.2(0.7)$ & $34(11)$ \\
\hline Blood & $25(11)$ & $180(71)$ & $320(62)$ & $72(23)$ & $21(3)$ & $520(160)$ & $2800(970)$ \\
\hline Brain & $200(70)$ & $270(66)$ & $400(130)$ & $110(24)$ & $89(12)$ & $170(28)$ & $1800(470)$ \\
\hline Kidneys & $\begin{array}{l}0.93 \\
(0.24)\end{array}$ & $1.4(0.1)$ & $4.6(1.1)$ & $3.1(0.4)$ & $\begin{array}{l}0.69 \\
(0.13)\end{array}$ & $0.80(0.06)$ & $24(8)$ \\
\hline Liver & $9.3(2.2)$ & $28(3)$ & $45(13)$ & $8.0(1.0)$ & $20(4)$ & $29(2)$ & $220(73)$ \\
\hline Lungs & $\begin{array}{l}0.62 \\
(0.16)\end{array}$ & $\begin{array}{l}0.99 \\
(0.10)\end{array}$ & $2.1(0.5)$ & $0.57(0.08)$ & $4.0(0.5)$ & $8.5(0.3)$ & $66(15)$ \\
\hline Spleen & $6.8(1.8)$ & $12(1.4)$ & $20(5.8)$ & $4.2(0.6)$ & $20(2)$ & 39 (2) & $150(56)$ \\
\hline
\end{tabular}

Table 3 Biodistribution of ${ }^{177}$ Lu-octreotate in IMR-32-bearing nude mice. Data is given as ${ }^{177}$ Lu activity concentration $(\% / \mathrm{A} / \mathrm{g})$ in each tissue and tumor-to-normal-tissue ${ }^{177}$ Lu activity concentration ratios (T/N) at 1, 24 and $168 \mathrm{~h}$ after injection of $15 \mathrm{MBq}{ }^{177}$ Lu-octreotate ( $n=5-6 /$ group). Values are given as mean (SEM)

\begin{tabular}{|c|c|c|c|}
\hline \multirow[b]{3}{*}{ Time p.i. } & \multicolumn{3}{|c|}{${ }^{177}$ Lu activity concentration $(\% / \mathrm{A} / \mathrm{g})$} \\
\hline & \multicolumn{3}{|l|}{$15 \mathrm{MBq}$} \\
\hline & $1 \mathrm{~h}$ & $24 \mathrm{~h}$ & $168 \mathrm{~h}$ \\
\hline Adrenals & $3.2(0.3)$ & $1.1(0.2)$ & $0.61(0.14)$ \\
\hline Blood & $2.3(0.3)$ & $\begin{array}{l}0.039 \\
(0.006)\end{array}$ & $\begin{array}{l}0.0087 \\
(0.0013)\end{array}$ \\
\hline Brain & $\begin{array}{l}0.22 \\
(0.02)\end{array}$ & $\begin{array}{l}0.046 \\
(0.003)\end{array}$ & $0.017(0.001)$ \\
\hline Kidneys & $43(3)$ & $18(1)$ & $1.4(0.1)$ \\
\hline Liver & $2.9(0.4)$ & $0.34(0.04)$ & $0.18(0.03)$ \\
\hline Lungs & $6.3(1.1)$ & $1.3(0.1)$ & $0.39(0.03)$ \\
\hline Spleen & $3.6(0.4)$ & $0.30(0.02)$ & $0.19(0.04)$ \\
\hline Tumor & $17(2)$ & $11(1)$ & $11(3)$ \\
\hline \multicolumn{4}{|c|}{ Tumor-to-normal-tissue concentration ratio $(\mathrm{T} / \mathrm{N})$} \\
\hline$T / N$ & $1 \mathrm{~h}$ & $24 \mathrm{~h}$ & $168 \mathrm{~h}$ \\
\hline Adrenals & $6.1(0.9)$ & $14(3)$ & $22(6)$ \\
\hline Blood & $8.8(1.1)$ & $330(46)$ & $1300(290)$ \\
\hline Brain & $86(12)$ & $330(84)$ & $740(190)$ \\
\hline Kidneys & $\begin{array}{l}0.38 \\
(0.04)\end{array}$ & $0.80(0.16)$ & $7.8(1.9)$ \\
\hline Liver & $6.9(0.9)$ & $41(7)$ & 70 (22) \\
\hline Lungs & $3.0(0.3)$ & $11(2)$ & $29(8)$ \\
\hline Spleen & $5.4(0.6)$ & 50 (12) & $100(47)$ \\
\hline
\end{tabular}

concentrations of ${ }^{177} \mathrm{Lu}$ (Tables 1, 2 and 3, Fig. 1, 2 and $3)$. The lungs showed an interesting pattern, where the ${ }^{177} \mathrm{Lu}$ concentration levels increased significantly as lower activity levels of ${ }^{177} \mathrm{Lu}$-octreotate were injected. For instance, mice bearing CLB-GE had 90\%IA/g in the lungs $1 \mathrm{~h}$ p.i. with $0.15 \mathrm{MBq}{ }^{177} \mathrm{Lu}$-octreotate and $6.4 \% \mathrm{IA} / \mathrm{g} 1 \mathrm{~h}$ p.i. with $15 \mathrm{MBq}{ }^{177} \mathrm{Lu}$-octreotate $(p=$ $0.0005)$. The kidneys did not show an equally strong activity dependency. For example, kidneys from mice bearing CLB-BAR xenograft tumors had ${ }^{177} \mathrm{Lu}$ concentrations of 58,61 and $57 \% \mathrm{IA} / \mathrm{g} 1 \mathrm{~h}$ p.i. with 0.15 , 1.50 and $15 \mathrm{MBq}{ }^{177} \mathrm{Lu}$-octreotate, respectively. In most cases, the adrenal glands had lower ${ }^{177} \mathrm{Lu}$ concentration levels than the kidneys and the lungs. The exception is mice bearing CLB-BAR xengraft tumors injected with $0.15 \mathrm{MBq}$, and then the adrenal glands received 36\% IA/g $24 \mathrm{~h}$ p.i. A rapid decline in blood activity level was detected in all models. Tumor-toblood $(\mathrm{T} / \mathrm{B})$ and tumor-to-kidney ratios $(\mathrm{T} / \mathrm{K})$ are presented in Fig. 4. CLB-GE had the highest $\mathrm{T} / \mathrm{B}$, 2300, $168 \mathrm{~h}$ p.i. with $15 \mathrm{MBq}$. T/B increased over time, with the exception being CLB-BAR and CLB-GE xenograft tumors after injection with $1.5 \mathrm{MBq}$ and $0.15 \mathrm{MBq}$, respectively. The highest $\mathrm{T} / \mathrm{K}$ value, 27, was observed in the CLB-GE xenograft bearing mice $168 \mathrm{~h}$ p.i. with $15 \mathrm{MBq}$. $\mathrm{T} / \mathrm{K}$ increased with time in all experiments. 


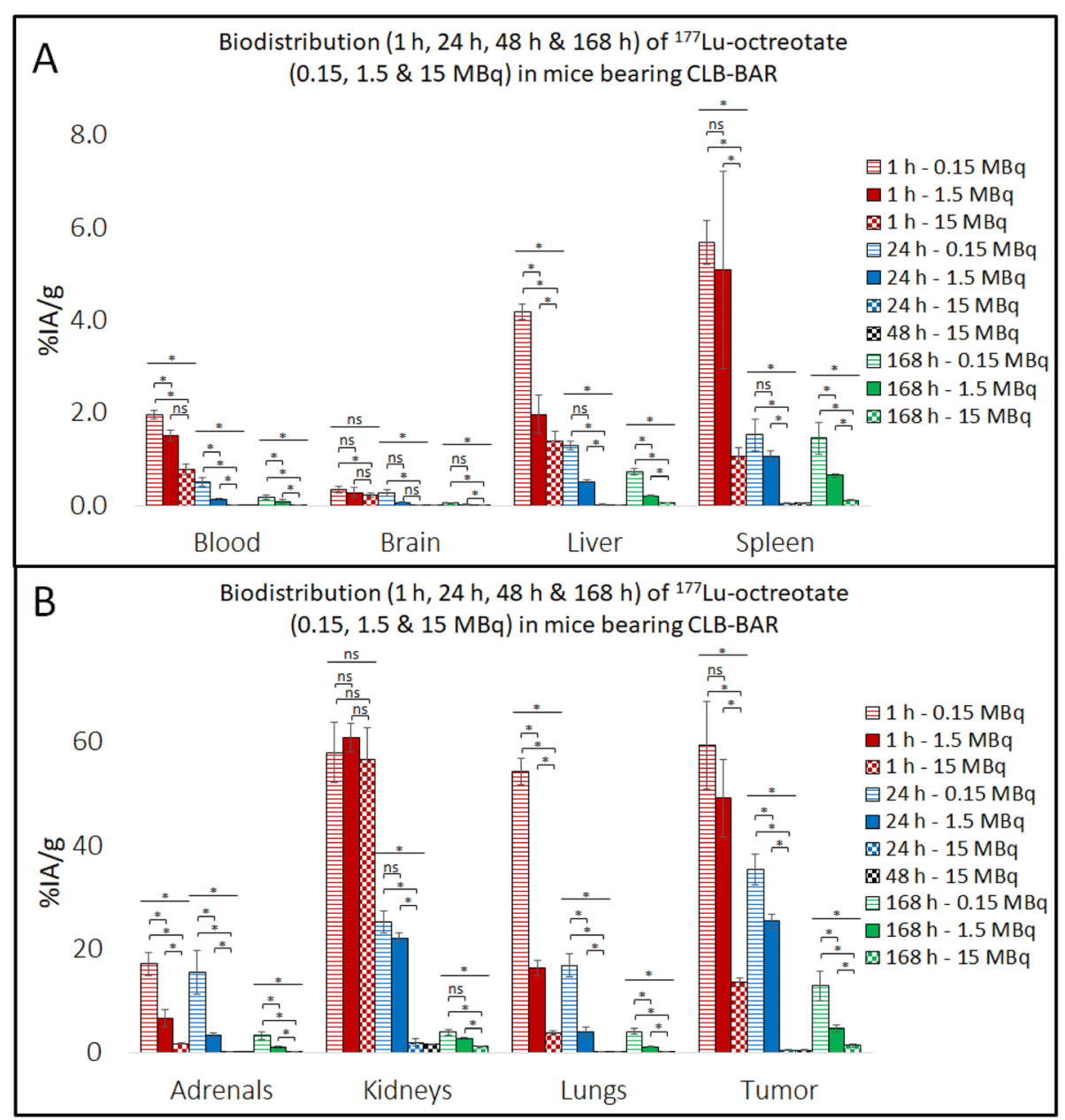

Fig. 1 Biodistribution of ${ }^{177}$ Lu-octreotate in CLB-BAR-bearing nude mice at $1 \mathrm{~h}, 24 \mathrm{~h}, 48 \mathrm{~h}$ and $168 \mathrm{~h}$ post injection with $0.15,1.5$ or $15 \mathrm{MBq}$. The concentration levels of ${ }^{177} \mathrm{Lu}(\% \mathrm{I} / \mathrm{g})$ were measured in each tissue at the given time-points $(n=5-6 /$ group). Note the different scales on $\mathrm{Y}$-axis in $\mathbf{A}$ and $\mathbf{B}$. Error-bars indicate the SEM in respective group. A one-way ANOVA was performed for comparing the means of the groups. Significant and non-significant differences between the groups are represented with "*" and "ns", respectively

\section{Dosimetry}

The mean absorbed dose per injected activity of ${ }^{177} \mathrm{Lu}$ octreotate $\left(D / A_{\text {inj }}\right)$ is presented in Table 4 for CLB-BAR, CLB-GE and IMR-32, respectively. In the mice bearing CLB-BAR xenograft tumors the mean absorbed dose to the tumor was $6.8 \mathrm{~Gy}$ and the kidneys received $19 \mathrm{~Gy}$ after administrating $15 \mathrm{MBq}{ }^{177} \mathrm{Lu}$-octreotate. Corresponding values after administering $1.5 \mathrm{MBq}$ were $4.4 \mathrm{~Gy}$ and 4.1 Gy for the tumor and kidneys, respectively. Corresponding values after administrating $0.15 \mathrm{MBq}$ were $0.53 \mathrm{~Gy}$ and $0.31 \mathrm{~Gy}$ for the tumor and kidneys, respectively. By increasing the administered activity first from $0.15 \mathrm{MBq}$ to $1.5 \mathrm{MBq}$ and further to $15 \mathrm{MBq}$ the D/A of the tumor tissue decreased with 17 and $87 \%$, respectively. In the mice bearing CLB-GE xenograft tumors the mean absorbed dose to the tumor was $53 \mathrm{~Gy}$ and the kidneys received $16 \mathrm{~Gy}$ after administering $15 \mathrm{MBq}$ ${ }^{177} \mathrm{Lu}$-octreotate. Corresponding values after administering $0.15 \mathrm{MBq}$ were $0.37 \mathrm{~Gy}$ and $0.31 \mathrm{~Gy}$ for the tumor and kidneys, respectively. The lungs had the highest $\mathrm{D} / \mathrm{A}_{\text {inj }}$ value with 4.6 for $0.15 \mathrm{MBq}$ with a mean absorbed dose of $0.69 \mathrm{~Gy}$. Increasing the administered activity from $0.15 \mathrm{MBq}$ to $15 \mathrm{MBq}$ resulted in a $45 \%$ increase of the $\mathrm{D} / \mathrm{A}_{\mathrm{inj}}$ for the tumor tissue, but reduced $\mathrm{D} /$ $A_{\text {inj }}$ values for all other tissues, with the lungs having the largest reduction of $94 \%$. The mice bearing IMR-32 xenograft tumors were injected with $15 \mathrm{MBq}$ only, from which the tumor and the kidneys received 29 Gy and 22 Gy, respectively.

\section{Immunohistochemical staining}

Tumor tissue from respective NB cell line derived xenografts were stained for expression of SSTR1-5 and Ki67 (Figs. 5 and 6). Higher expression of SSTR2 was demonstrated, in comparison with other SSTR subtypes, for all xenografts (Fig. 5). CLB-GE xenograft tumors demonstrated a more 


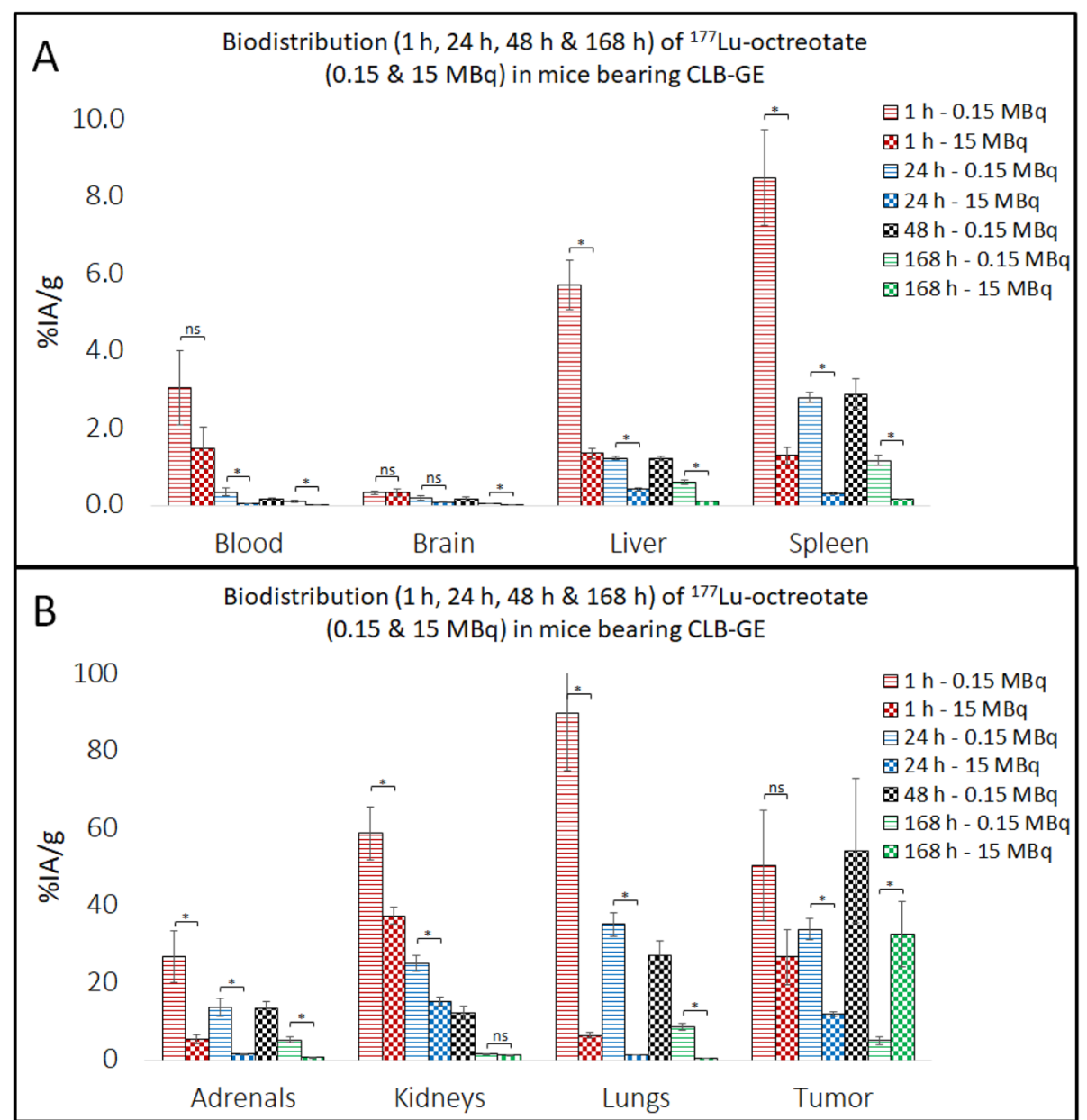

Fig. 2 Biodistribution of ${ }^{177}$ Lu-octreotate in CLB-GE-bearing nude mice at 1 h, 24 h, 48 h (only for $0.15 \mathrm{MBq}$ ) and $168 \mathrm{~h}$ p.i. with $0.15 \mathrm{MBq}$ or 15 MBq. The concentration levels of ${ }^{177} \mathrm{Lu}(\% \mathrm{IA} / \mathrm{g})$ were measured in each tissue at the given time-points $(n=5-6 / g r o u p)$. Note the different scales on $\mathbf{Y}$-axis in $\mathbf{A}$ and $\mathbf{B}$. Error-bars indicate SEM in respective group. A one-way ANOVA was performed for comparing the means of the groups. Significant and non-significant differences between the groups are represented with "**" and "ns", respectively

specific and intense expression of SSTR2, followed by CLBBAR and IMR-32 xenografts, respectively. The relative differences in SSTR expression between the cell lines were not as pronounced for the other receptor subtypes. SSTR3-staining provided the second, relatively highest expression. Staining for SSTR1, SSTR4 and SSTR5 did not demonstrate clear receptor expression in any NB xenograft investigated. Staining with anti-Ki-67 confirmed cellular proliferation in each tumor tissue (Fig. 6).

\section{Discussion}

There have been great advances in the treatment of patients with NB over the last decades. The overall survival rate for all NB patients has increased to approximately $80 \%$, but for HR-NB patients overall survival rate is still only about $40 \%$ [5]. This patient group has not responded as well as low-risk NB patients to the newly introduced treatment methods. There is thus a need for novel treatment modalities for patients with HR-NB, where ${ }^{177} \mathrm{Lu}$-octreotate could be a potential option if necessary dosimetric and radiosensitivity requirements are fulfilled. Knowledge of biodistribution and biokinetics of the radiopharmaceutical is needed in order to be able to determine if a compound is suitable for diagnostic and therapeutic purposes for each new type of cancer. When it comes to radionuclide therapy, it is most often the absorbed dose to the critical organs that will limit the activity level possible to administer. The present study was performed in order to examine the biokinetics and biodistribution of ${ }^{177} \mathrm{Lu}$-octreotate in three aggressive human NB xenograft models: CLB-BAR, CLB-GE and IMR-32. The results demonstrated high ${ }^{177} \mathrm{Lu}$ activity concentration levels in the xenograft tumor tissue arising from all three NB cell lines. The differences in ${ }^{177} \mathrm{Lu}$ activity concentration between the NB cell lines may be due to differences in overall SSTR expression, SSTR 


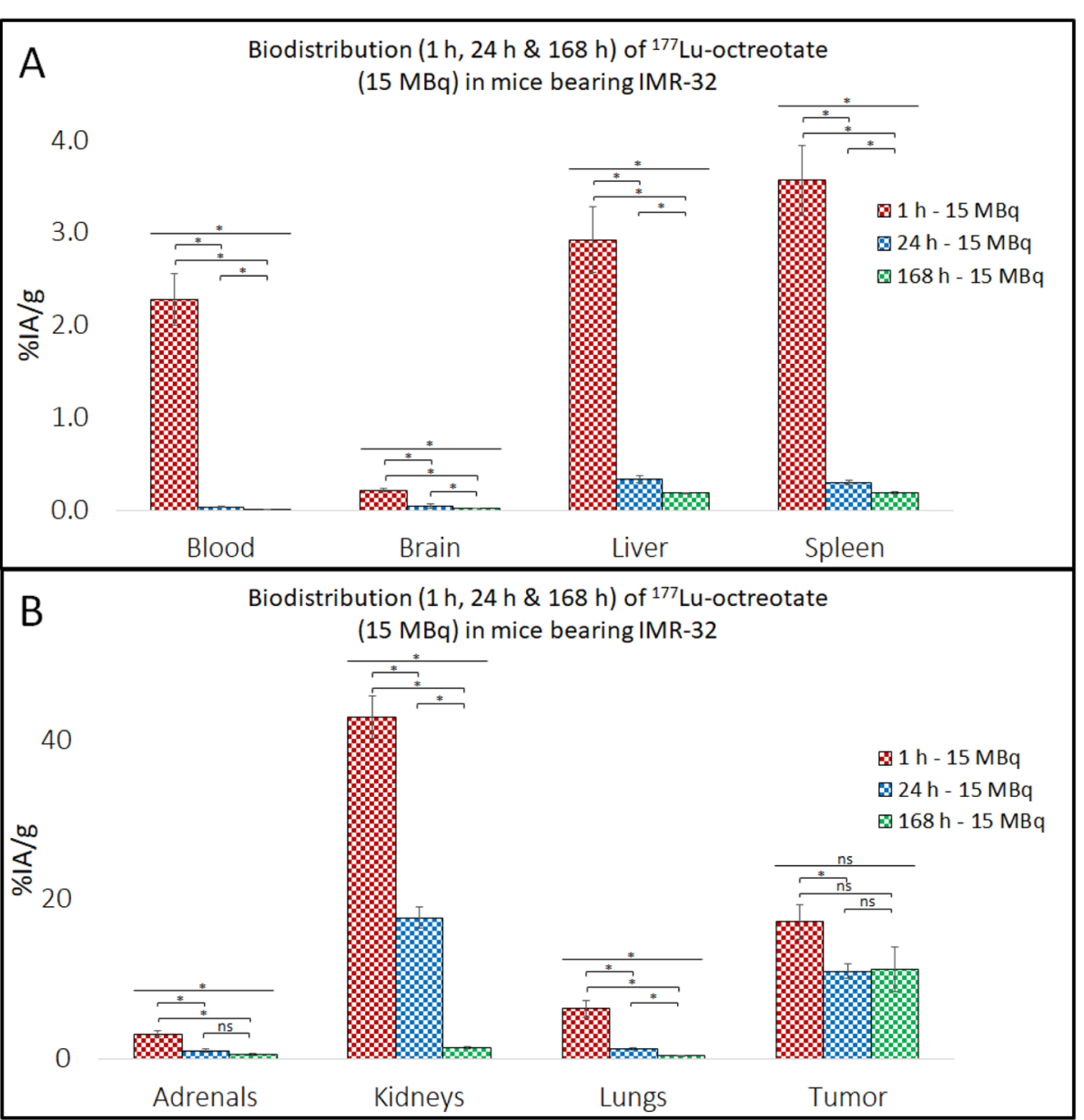

Fig. 3 Biodistribution of ${ }^{177}$ Lu-octreotate in IMR-32-bearing nude mice at $1 \mathrm{~h}, 24 \mathrm{~h}$ and $168 \mathrm{~h}$ p.i. with $15 \mathrm{MBq}$. The concentration levels of ${ }^{177} \mathrm{Lu}$ $(\% / \mathrm{A} / \mathrm{g})$ were measured in each tissue at the given time-points ( $n=5 / g r o u p)$. Note the different scales on $\mathrm{Y}$-axis in $\mathbf{A}$ and $\mathbf{B}$. Error-bars indicate SEM in respective group. A one-way ANOVA was performed for comparing the means of the groups. Significant and non-significant differences between the groups are represented with "*" and "ns", respectively

subtype expression and receptor saturation for higher amounts of octreotate administered. CLB-GE xenograft tumors had the highest uptake, while CLB-BAR xenografts demonstrated saturation effects at the higher activity levels and hence had the lowest uptake. IMR-32 xenograft tumors had lower uptake of ${ }^{177}$ Lu-octreotate in comparison with CLB-GE, but still displayed a relatively long retention rate of ${ }^{177} \mathrm{Lu}$-octreotate.

In all but one experiment, the ${ }^{177} \mathrm{Lu}$ concentration in the tumor tissues decreased with time during the $168 \mathrm{~h}$ interval studied, regardless of the amount injected. However, when the CLB-GE xenograft bearing mice were injected with $15 \mathrm{MBq}{ }^{177} \mathrm{Lu}$-octreotate, the ${ }^{177} \mathrm{Lu}$ concentration in tumor did not decrease from $1 \mathrm{~h}$ to $168 \mathrm{~h}$ p.i, a finding not detected after 0.15 MBq. One explanation can be a higher accumulation in tumor tissue due to a therapeutic effect resulting in tumor volume reduction, a phenomenon we have observed in our previous studies on the human small intestinal NET GOT1 model
[35, 38-41]. For patients with advanced midgut NETs, ${ }^{177} \mathrm{Lu}$-octreotate has proven to be a treatment that increases the progression-free survival and the overall survival [42]. Therefore, ${ }^{177} \mathrm{Lu}$-octreotate (Lutathera ${ }^{\circ}$ ) is now FDA and EMA approved for treatment of SSTRpositive midgut, foregut and hindgut NETs. Hence it is of interest to compare data from our NB models with similar from the GOT1-model. Solely observing the concentration levels of ${ }^{177} \mathrm{Lu}$ in the tumor tissues in the different tumor models it becomes clear that all xenografts derived from NB cell lines have similar or higher tumor uptake relative to other NET models (Table 5). The differences between the cell lines are evident also when the $\mathrm{T} / \mathrm{B}$ and the $\mathrm{T} / \mathrm{K}$ values are compared (Fig. 4).

In general, lower ${ }^{177} \mathrm{Lu}$ concentration levels in tumors were observed after administration of $15 \mathrm{MBq}{ }^{177} \mathrm{Lu}$ octreotate compared with lower amounts administered. One explanation for this finding may be saturation of the SSTRs. Although internalization of SSTRs occurs after a 


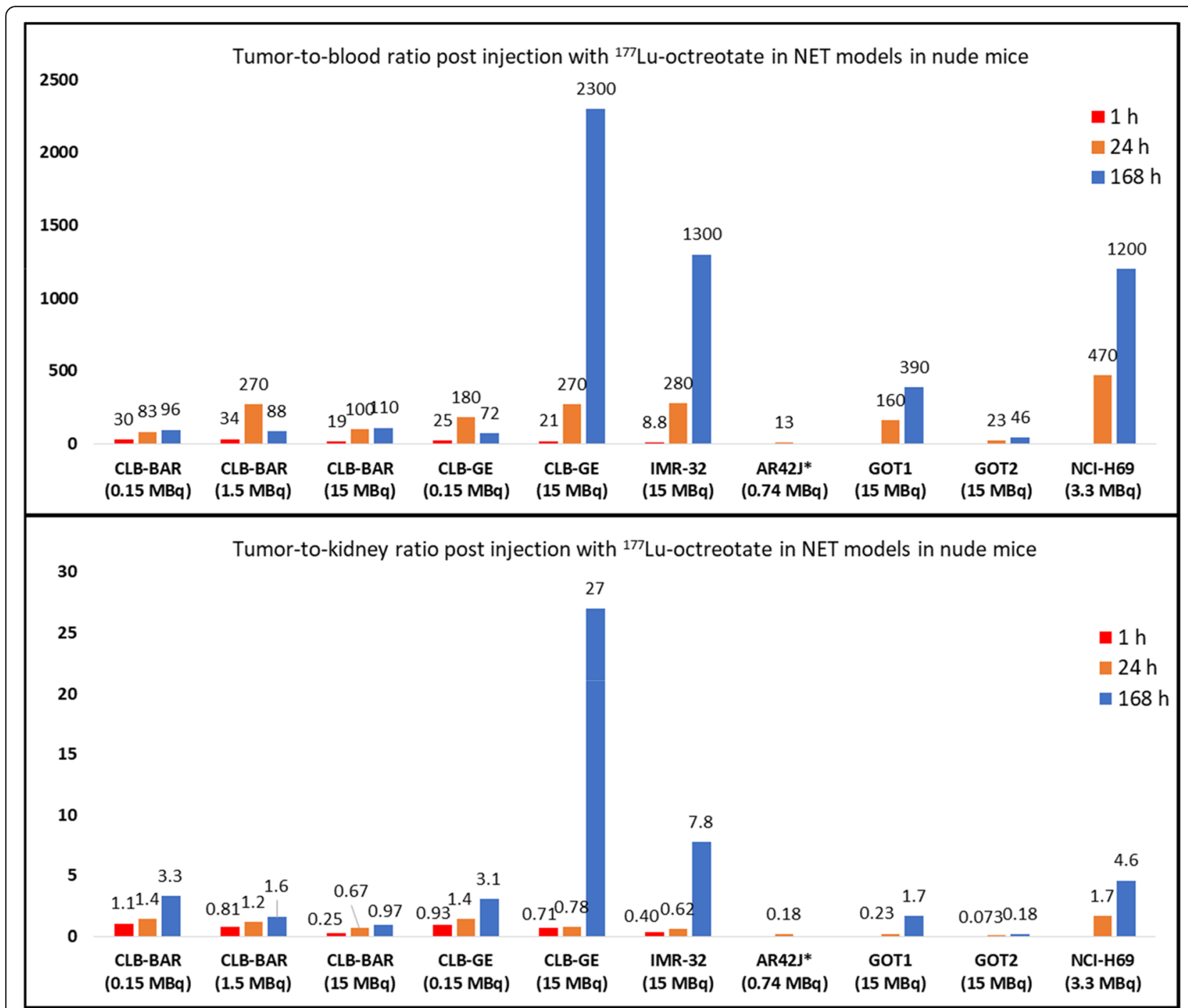

Fig. 4 Tumor-to-blood and tumor-to-kidney ${ }^{177}$ Lu activity concentration ratios in NET xenograft models: CLB-BAR (present study), CLB-GE (present study), IMR-32 (present study), AR42J, GOT1, GOT2 and NCI-H69 at $1 \mathrm{~h}, 24 \mathrm{~h}$ and $168 \mathrm{~h}$ post injection with ${ }^{177}$ Lu-octreotate. The data for NB cell lines xenografts (CLB-BAR, CLB-GE and IMR-32) were compared with corresponding values for rat pancreatic tumor (AR42J*) small intestine neuroendocrine tumor (GOT1), medullary carcinoma (GOT2) and human small cell lung cancer (NCl-69) in nude mice. The activity injected is presented in parentheses. ${ }^{*}$ indicates rat origin and of exocrine type. The other cells or cell lines are human

few minutes, $2.5 \mathrm{~min}$ in rats [47], saturation effects are still prominent [48]. Saturation of SSTRs are prevented by fractionated administration, which may also result in upregulation of SSTR expression that may also further increase the uptake and hence therapeutic effect [16].

The high uptake of ${ }^{177} \mathrm{Lu}$-octreotate in CLB-GE tumors compared with that of the CLB-BAR and IMR-32 xenografts may be explained by the high SSTR2 expression of the CLB-GE xenograft tumors demonstrated by IHC, since octreotate has a higher affinity for SSTR2 than for the other SSTR subtypes [23]. However, assuming solely that high receptor expression leads to high tumor uptake and absorbed dose is a somewhat simplified picture of reality. This is demonstrated when the
SSTR2 expression for CLB-BAR and IMR-32 xenografts is compared. Our IHC data indicate that CLB-BAR xenografts has a higher expression of SSTR2 than IMR-32 xenografts, while the mean absorbed dose for IMR-32 tumors was higher than for CLB-BAR. There are many reasons that may explain these discrepancies, e.g. that the affinity to the other SSTR subtypes are of importance, primarily SSTR4 and SSTR5, together with other functional differences between SSTR subtypes, such as receptor internalization, receptor cycling, receptor saturation and radionuclide retention. However, the main reason is most probably that binding of ${ }^{177} \mathrm{Lu}$-octreotate can only occur to SSTRs expressed on the outside of cell membrane, while the IHC images visualize all SSTRs 
Table 4 Mean absorbed dose per amount of injected activity (Gy/MBq) for CLB-BAR (present study), CLB-GE (present study), IMR-32 (present study), GOT1, GOT2 and NCl-H69. Data were corrected for decay before estimation of the absorbed dose

\begin{tabular}{|c|c|c|c|c|c|c|c|c|c|}
\hline \multirow{2}{*}{$\begin{array}{l}\text { Cell line } \\
\text { Activity injected }\end{array}$} & \multicolumn{3}{|c|}{$\begin{array}{l}\text { CLB-BAR } \\
\text { (present study) }\end{array}$} & \multicolumn{2}{|c|}{$\begin{array}{l}\text { CLB-GE } \\
\text { (present study) }\end{array}$} & \multirow{2}{*}{$\begin{array}{l}\text { IMR-32 } \\
\text { (present study) } \\
15 \\
\text { MBq }\end{array}$} & \multirow{2}{*}{$\begin{array}{l}\text { GOT1 [35] } \\
15 \\
\mathrm{MBq}\end{array}$} & \multirow{2}{*}{$\begin{array}{l}\text { GOT2 [36] } \\
10 \\
\mathrm{MBq}\end{array}$} & \multirow{2}{*}{$\begin{array}{l}\mathrm{NCl}-\mathrm{H} 69 \text { [37] } \\
3.3 \\
\mathrm{MBq}\end{array}$} \\
\hline & $\begin{array}{l}0.15 \\
\mathrm{MBq}\end{array}$ & $\begin{array}{l}1.5 \\
\mathrm{MBq}\end{array}$ & $\begin{array}{l}15 \\
\mathrm{MBq}\end{array}$ & $\begin{array}{l}0.15 \\
\mathrm{MBq}\end{array}$ & $\begin{array}{l}15 \\
\mathrm{MBq}\end{array}$ & & & & \\
\hline Adrenals & 1.4 & 0.30 & 0.096 & 1.9 & 0.24 & 0.15 & 0.079 & 0.051 & - \\
\hline Blood & 0.063 & 0.029 & 0.0061 & 0.14 & 0.042 & 0.014 & 0.00069 & 0.00056 & - \\
\hline Brain & 0.090 & 0.0091 & 0.0065 & 0.018 & 0.011 & 0.0065 & - & - & - \\
\hline Kidneys & 2.1 & 2.7 & 1.3 & 2.1 & 1.1 & 1.4 & 0.32 & 0.32 & - \\
\hline Liver & 0.18 & 0.067 & 0.029 & 0.31 & 0.052 & 0.085 & 0.011 & 0.0091 & - \\
\hline Lungs & 1.8 & 0.46 & 0.10 & 4.6 & 0.26 & 0.16 & 0.038 & - & - \\
\hline Spleen & 0.22 & 0.16 & 0.049 & 0.54 & 0.057 & 0.061 & 0.012 & 0.0079 & - \\
\hline Tumor & 3.6 & 2.9 & 0.45 & 2.4 & 3.6 & 1.9 & 0.27 & 0.013 & 0.29 \\
\hline
\end{tabular}

expressed in tissue, also the intracellularly distributed receptors. Thus no quantitative analyses were performed on the IHC images.

A prerequisite for the therapeutic use of radiolabeled SS analogs is high expression of SSTRs. Our results demonstrate high expression of SSTR in these NB xenograft models. Previous study demonstrated frequent expression of SSTR subtypes in NB xenograft models: SH-SY5Y, SK-N-DZ, SK-N-AS, IMR-32 and KELLY, which is in line with our results [17]. High expression of SSTR2 has also been reported in other NB xenograft models $[22,49]$. A case-study of 54 NB patients reported SSTR2 expression in 44 patients, with 19 of 27 HR-NB patients expressing SSTR2 [18], confirming similar

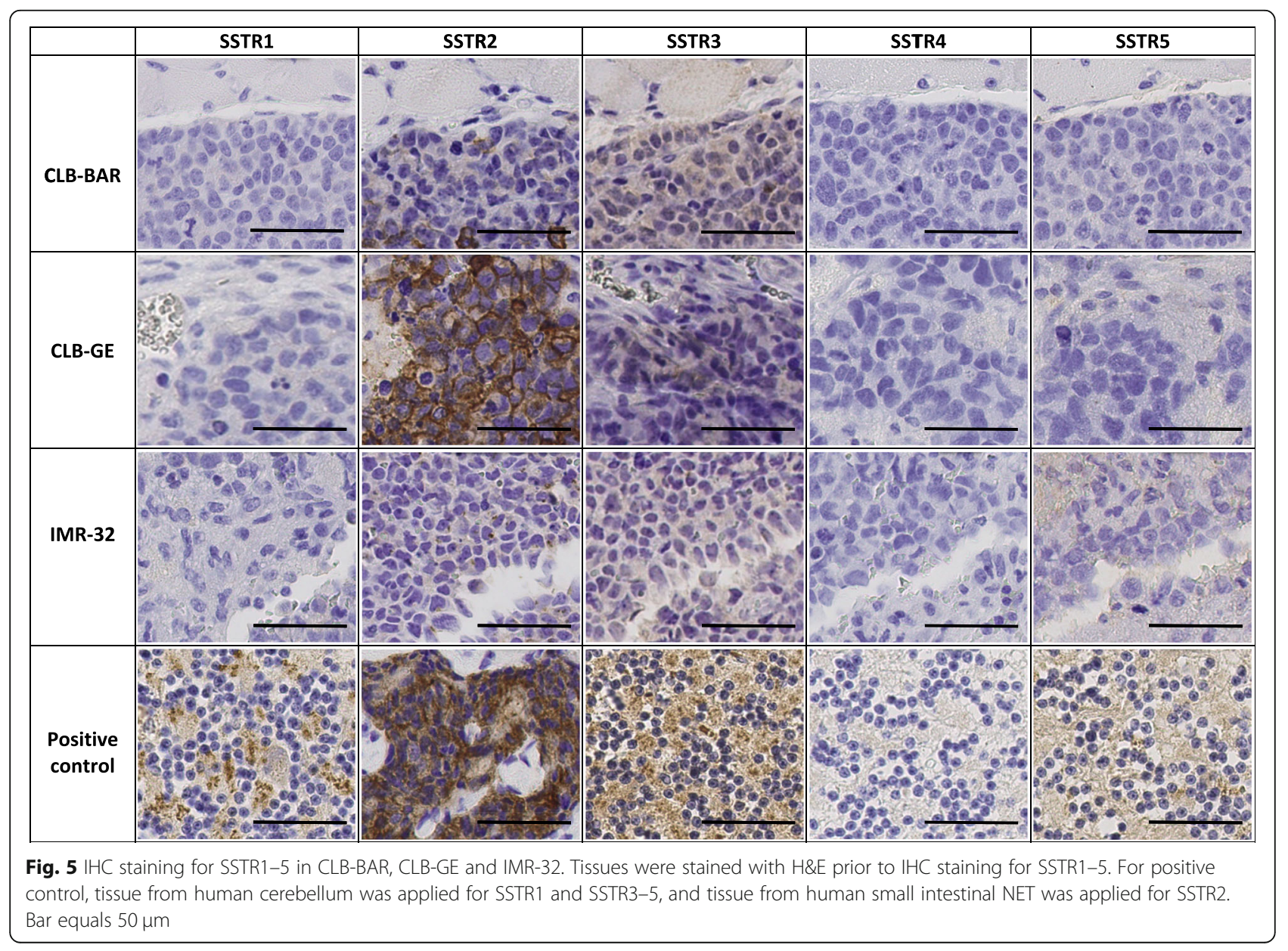




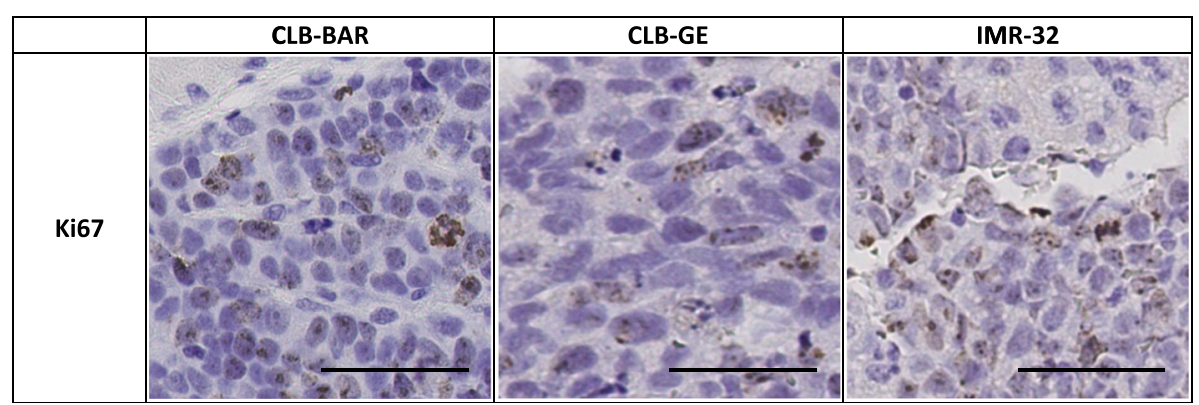

Fig. $6 \mathrm{HC}$ staining for Ki67 in CLB-BAR, CLB-GE and IMR-32. Tissues were stained with H\&E prior to IHC staining for Ki67. Bar equals $50 \mu \mathrm{m}$

studies and conveys SSTR2 expression in HR-NB [17, 19, 20]. A recent study could, through personalized treatment with ${ }^{90} \mathrm{Y}-,{ }^{111} \mathrm{In}$ - and/or ${ }^{177} \mathrm{Lu}$-labeled octreotate in combination with chemotherapy, demonstrate partial responses in all four HR-NB patients who previously did not responded to multimodal treatments [20]. Our results and prior research highlights the diagnostic and therapeutic potentials of targeting SSTR2 in NB patients with radiolabeled SS analogues. Analyzing the R2 database demonstrates that SSTR2 is the most abundantly expressed SSTR subtype in NB tumors (http://r2. amc.nl). Furthermore, previous data on the transcriptional expression of the various SSTR subtypes in CLBBAR, CLB-GE and IMR-32 support the high SSTR2 expression in our IHC data (Fig. 7) [50, 51]. Our IHC findings may also indicate, in contrast to the mRNA expression, that SSTR3 could be a useful target for treatment. In that regard the SS analogue, octreotide, is preferable due to its higher affinity to SSTR3 in comparison with octreotate [23]. Mapping the SSTR subtypes of the tumor before treatment can promote the choice of tumor seeking agents.

The kidneys, lungs and adrenal glands were consistently the three organs with the highest concentrations of ${ }^{177} \mathrm{Lu}$. The adrenals and kidneys are known to express SSTRs. High kidney uptake of ${ }^{177} \mathrm{Lu}$-octreotate has been observed in biodistribution studies before [35, 46, 52], demonstrating the well-known fact that the kidneys are one of the main organs at risk. This is due to the fact that mouse kidneys express SSTR1-5 as well as the tubular reabsorption process [53,54]. Also the lungs in mice have demonstrated expression of SSTR1-5 [55], which may explain the relative high uptake of ${ }^{177} \mathrm{Lu}$ octreotate in the present study. Furthermore, for these three tissue types the ${ }^{177} \mathrm{Lu}$ concentration decreased significantly with higher amounts of ${ }^{177} \mathrm{Lu}$-octreotate injected, demonstrating a potential saturation of SSTRs, a phenomenon previously demonstrated in non-tumor

Table 5 Concentration of ${ }^{177} \mathrm{Lu}(\% / \mathrm{A} / \mathrm{g})$ in tumor tissue in NET xenograft models at $1 \mathrm{~h}, 24 \mathrm{~h} 48 \mathrm{~h}$ and $168 \mathrm{~h}$ post injection of ${ }^{177} \mathrm{Lu}-$ octreotate. The tumor-to-kidney (T/K) and tumor-to-blood (T/B) ratio is presented for $24 \mathrm{~h}$ post injection

\begin{tabular}{|c|c|c|c|c|c|c|c|c|c|}
\hline \multirow[t]{2}{*}{ Cell line } & \multirow[t]{2}{*}{ Study } & \multirow{2}{*}{$\begin{array}{l}\text { Animal } \\
\text { model(s) }\end{array}$} & \multirow{2}{*}{$\begin{array}{l}\text { Inj. } \\
\text { activity }\end{array}$} & \multicolumn{6}{|c|}{${ }^{177}$ Lu activity concentration $(\% \mid A / g)$} \\
\hline & & & & $1 \mathrm{~h}$ & $24 \mathrm{~h}$ & $48 \mathrm{~h}$ & $168 \mathrm{~h}$ & $\mathrm{~T} / \mathrm{K}(24 \mathrm{~h})$ & T/B (24h) \\
\hline$\overline{A R 42 J^{a}}$ & De Araújo et al. [43] & nude mice & $0.74 \mathrm{MBq}$ & 2.4 & 0.8 & 0.6 & - & 0.18 & 13 \\
\hline CA20948 ${ }^{\mathrm{a}}$ & Lewis et al. [44] & rat & $1.3 \mathrm{MBq}$ & 3.9 & 6.1 & - & 0.65 & 3.6 & 200 \\
\hline CA20948 & de Jong et al. [45] & rat & $3 \mathrm{MBq}$ & - & 2.2 & - & - & 1.4 & 1100 \\
\hline GOT1 & Dalmo et al. [35] & nude mice & $15 \mathrm{MBq}$ & - & 1.6 & - & 0.84 & 0.23 & 160 \\
\hline GOT2 & Dalmo et al. [46] & nude mice & $5.0 \mathrm{MBq}$ & - & 0.37 & - & 0.094 & 0.073 & 23 \\
\hline GOT2 & Dalmo et al. [46] & nude mice & $10 \mathrm{MBq}$ & - & 0.23 & - & 0.039 & 0.038 & 26 \\
\hline $\mathrm{NCl}-\mathrm{H} 69$ & Schmitt et al. [37] & nude mice & $3.3 \mathrm{MBq}$ & - & 3.7 & - & 1.2 & 1.7 & 470 \\
\hline CLB-BAR & Present study & nude mice & $0.15 \mathrm{MBq}$ & 59 & 36 & - & 13 & 83 & 1.4 \\
\hline CLB-BAR & Present study & nude mice & $1.5 \mathrm{MBq}$ & 49 & 25 & - & 4.6 & 270 & 1.2 \\
\hline CLB-BAR & Present study & nude mice & $15 \mathrm{MBq}$ & 14 & 0.53 & 0.53 & 1.5 & 100 & 0.67 \\
\hline CLB-GE & Present study & nude mice & $0.15 \mathrm{MBq}$ & 50 & 34 & 54 & 5 & 180 & 1.4 \\
\hline CLB-GE & Present study & nude mice & $15 \mathrm{MBq}$ & 27 & 12 & - & 33 & 520 & 0.80 \\
\hline IMR-32 & Present study & nude mice & $15 \mathrm{MBq}$ & 17 & 11 & - & 11 & 330 & 0.80 \\
\hline
\end{tabular}

${ }^{\mathrm{a}}$ indicates rat origin and of exocrine type. The other cells or cell lines are human 
bearing C57 mice, but also for ${ }^{111}$ In-octreotide in tumor-bearing nude mice $[48,52]$. In general, these tissues had lower retention rate of ${ }^{177} \mathrm{Lu}$ compared with tumor tissue, resulting in increasing tumor-to-normaltissue values with time. The clearly different biokinetic pattern of ${ }^{177} \mathrm{Lu}$ in lungs and kidneys, respectively, for the CLB-BAR and CLB-GE xenograft bearing mice remains to be clarified. The majority of the normal tissues demonstrated a decrease in ${ }^{177} \mathrm{Lu}$ concentration with time. Exceptions were found in the CLB-BAR mice for the kidneys $(1.5 \mathrm{MBq})$ and adrenals $(0.15 \mathrm{MBq})$ with maxima at $24 \mathrm{~h}$ p.i.

Two important parameters related to the potential success in treatment with ${ }^{177} \mathrm{Lu}$-octreotate are tumor-toblood $(\mathrm{T} / \mathrm{B})$ and tumor-to-kidney $(\mathrm{T} / \mathrm{K})$ values, since the bone marrow and the kidneys are the main risk organs in this treatment modality. T/B increased with time in most experiments, and $\mathrm{T} / \mathrm{K}$ in all experiments, which is highly beneficial for future therapy. Furthermore, T/B and $\mathrm{T} / \mathrm{K}$ for the CLB-GE and IMR-32 xenografts were higher than corresponding values reported for the human small-intestinal NET GOT1 animal model, which we have long-term experience of as a realistic model for the patient situation, and where curative effects are obtained with ${ }^{177} \mathrm{Lu}$-octreotate $[38,40]$. The estimated absorbed dose confirmed the high tumor uptake for all NB xenografts, with the tumor receiving higher dose in comparison with the kidneys in all experiments except for one. Altogether, the biokinetic data for the examined NBs and potential therapeutic effects for CLB-GE already at these low amounts, clearly demonstrate that ${ }^{177} \mathrm{Lu}$-octreotate therapy can be very effective in these types of NB.

The present study was performed in immunocompromised Balb/c nude mice xenografted with human tumor cells, which is a well-established model type

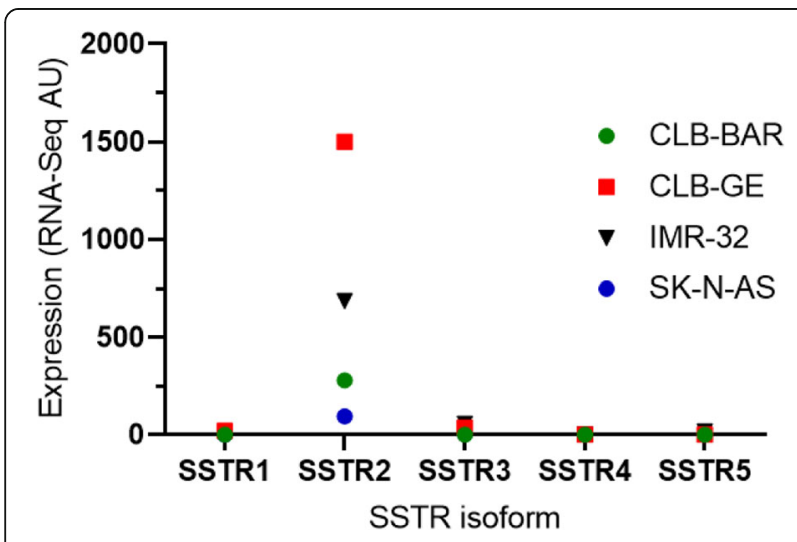

Fig. 7 mRNA expression of SSTR1-5 in NB cell lines CLB-BAR, CLBGE, IMR-32 and SK-N-AS. Data were extracted from Van den Eynden et al. [50] and Borenäs et al. [51]. SK-N-AS was present in both studies and were used to normalize data from the two studies, for comparison frequently used in translational research and enables in vivo studies on human tumor tissue. In recent years, the importance of the immune system on the radiation induced tumor response in radiation therapy has been investigated [56], and the choice of animal strain for preclinical models could then be of importance. However, the present study is only related to biodistribution of the radiopharmaceutical, which is highly related to the SSTR-expression at the tumor cell surface, which most probably is less dependent on the immune system. Furthermore, our previous similar biodistribution studies on other neuroendocrine tumor types in this nude mouse model have demonstrated similar data in the animal models and in the patients who donated the tumor tissue [57], which supports the interpretation and translation of the findings in the present study.

In future studies, we will examine the potential of combining two different radiopharmaceuticals. In theory it would be beneficial to combine ${ }^{131} \mathrm{I}-\mathrm{MIBG}$ and ${ }^{177} \mathrm{Lu}$ octreotate, since the biokinetics in risk organs differs between the two radiopharmaceuticals. Then, the absorbed dose to the tumor tissue might be higher, while keeping the absorbed dose to the risk organs acceptable.

\section{Conclusion}

In conclusion, the biodistribution studies of ${ }^{177} \mathrm{Lu}$ octreotate in all three investigated human NB xenograft mouse models demonstrated very high uptake in tumors compared with that in normal tissues. Therefore, ${ }^{177} \mathrm{Lu}$ octreotate should be considered a potential systemic treatment option, especially in high risk NB patients with high expression of SSTRs and with low response to present treatment options.

\section{Abbreviations}

NB: Neuroblastoma; SSTR: Somatostatin receptors; T/N: Tumor-to-normaltissue activity concentration ratios; $1 \mathrm{HC}$ : Immunohistochemistry; p.i.: Post injection; NETs: Neuroendocrine tumors; INRG: International Neuroblastoma Risk Group; MNA: MYCN amplification; HR: High-risk; EFS: Event-free surivival; ASCT: Autologous peripheral blood stem cell transplantation; MIBG: Metaiodobenzylguanidine; SS: Somatostatin; s.c.: Subcutaneous; i.V.: Intravenous; FBS: Fetal bovine serum; ITLC-SG: Instant thin layer chromatography Silica-Gel; ARRIVE: Animal Research Reporting of In Vivo Experiments; MIRD: Medical Internal Radiation Dose; SEM: Standard error of mean; H\&E: Hematoxylin and eosin; FFPE: Formalin-fixed, paraffin-embedded; $D / A_{\text {inj: }}$ : Dose per injected activity

\section{Acknowledgements}

The authors thank Techn. Ann Wikström for her skilled performance of the animal studies and the tissue processing.

\section{Authors' contributions}

$A R, J S, B H, R H P$ and EFA conceptualized the study. AR, JS, BH, RHP and EFA designed the study. AR, DEL and ES carried out the animal experiment. ES performed IHC. AR, JS and EFA contributed to the data analysis and interpretation. AR wrote the original draft. All authors reviewed and edited the manuscript. The authors read and approved the final manuscript. 


\section{Funding}

This study was supported by grants from the Swedish Research Council (grants no. EFA: 21073; RHP: 03914; BH: 01324), the Swedish Cancer Society (grants no. EFA: 3427; RHP: 729; BH: 718), Swedish Childhood Cancer Fund, BioCARE - a National Strategic Research Program at the University of Gothenburg, the Swedish state under the agreement between the Swedish government and the county councils - the ALF-agreement (ALFGBG725031), the King Gustav V Jubilee Clinic Cancer Research Foundation, the Sahlgrenska University Hospital Research Funds, the Assar Gabrielsson Cancer Research Foundation, the Adlerbertska Research Foundation, and the Wilhelm and Martina Lundgren Science Fund. Open Access funding provided by University of Gothenburg.

\section{Availability of data and materials}

All data generated or analysed during this study are included in this published article.

\section{Declarations}

\section{Ethics approval and consent to participate}

All animal experiments were approved by the Ethical Committee on Animal Experiments in Gothenburg, Sweden (reference number: 107-15) on behalf of the Swedish National Committee for the Protection of Animals used for Scientific Purposes. The study was conducted in accordance with guidelines from Animal Research: Reporting of In Vivo Experiments (ARRIVE) and all methods were carried out in accordance with relevant guidelines and regulations.

\section{Consent for publication}

Not applicable.

\section{Competing interests}

The authors declare no competing interests.

\section{Author details}

'Department of Medical Radiation Sciences, Institute of Clinical Sciences, Sahlgrenska Center for Cancer Research, Sahlgrenska Academy, University of Gothenburg, Gothenburg, Sweden. ${ }^{2}$ Department of Medical Physics, Sahlgrenska University Hospital, SE-41345 Gothenburg, Sweden. ${ }^{3}$ Department of Medical Biochemistry and Cell Biology, Institute of Biomedicine, Sahlgrenska Center for Cancer Research, Sahlgrenska Academy, University of Gothenburg, Gothenburg, Sweden. ${ }^{4}$ Department of Medical Physics and Biomedical Engineering, Sahlgrenska University Hospital, Gothenburg, Sweden.

Received: 1 March 2021 Accepted: 14 June 2021

Published online: 25 August 2021

\section{References}

1. Maris JM, Hogarty MD, Bagatell R, Cohn SL. Neuroblastoma. Lancet. 2007; 369(9579):2106-20. https://doi.org/10.1016/S0140-6736(07)60983-0.

2. Castel V, Grau E, Noguera R, Martinez F. Molecular biology of neuroblastoma. Clin Transl Oncol. 2007;9(8):478-83. https://doi.org/10.1007/ s12094-007-0091-7.

3. Matthay KK, Maris JM, Schleiermacher G, Nakagawara A, Mackall CL, Diller L, et al. Neuroblastoma. Nat Rev Dis Prim. 2016;2(1):16078. https://doi.org/10.1 038/nrdp.2016.78.

4. Cohn SL, Pearson AD, London WB, Monclair T, Ambros PF, Brodeur GM, et al. The international neuroblastoma risk group (INRG) classification system: an INRG task force report. J Clin Oncol. 2009;27(2):289-97. https:// doi.org/10.1200/JCO.2008.16.6785.

5. Pinto NR, Applebaum MA, Volchenboum SL, Matthay KK, London WB, Ambros PF, et al. Advances in risk classification and treatment strategies for neuroblastoma. J Clin Oncol. 2015;33(27):3008-17. https://doi.org/10.1200/ JCO.2014.59.4648.

6. Nickerson HJ, Matthay KK, Seeger RC, Brodeur GM, Shimada H, Perez C, et al. Favorable biology and outcome of stage IV-S neuroblastoma with supportive care or minimal therapy: a Children's Cancer Group study. J Clin Oncol. 2000;18(3):477.

7. Siaw JT, Javanmardi N, Van den Eynden J, Lind DE, Fransson S, MartinezMonleon A, et al. 11q deletion or ALK activity curbs DLG2 expression to maintain an undifferentiated state in neuroblastoma. Cell Rep. 2020;32(12): 108171. https://doi.org/10.1016/j.celrep.2020.108171.

8. Smith V, Foster J. High-risk neuroblastoma treatment review. Children. 2018; 5(9):114.

9. Matthay KK, DeSantes K, Hasegawa B, Huberty J, Hattner RS, Ablin A, et al. Phase I dose escalation of 1311-metaiodobenzylguanidine with autologous bone marrow support in refractory neuroblastoma. J Clin Oncol. 1998;16(1): 229-36. https://doi.org/10.1200/JCO.1998.16.1.229.

10. Matthay KK, Weiss B, Villablanca JG, Maris JM, Yanik GA, DuBois SG, et al. Dose escalation study of no-carrier-added 1311-metaiodobenzylguanidine for relapsed or refractory neuroblastoma: new approaches to neuroblastoma therapy consortium trial. J Nucl Med. 2012;53(7):1155-63. https://doi.org/10.2967/jnumed.111.098624.

11. Chiu B, Coburn J, Pilichowska M, Holcroft C, Seib FP, Charest A, et al. Surgery combined with controlled-release doxorubicin silk films as a treatment strategy in an orthotopic neuroblastoma mouse model. $\mathrm{Br}$ J Cancer. 2014;111(4):708-15. https://doi.org/10.1038/bjc.2014.324.

12. Li H, Chen Z, Hu T, Wang L, Yu Y, Zhao Y, et al. Novel proteasome inhibitor ixazomib sensitizes neuroblastoma cells to doxorubicin treatment. Sci Rep. 2016;6(1):1-10.

13. Ladenstein R, Pötschger U, Pearson AD, Brock P, Luksch R, Castel V, et al. Busulfan and melphalan versus carboplatin, etoposide, and melphalan as high-dose chemotherapy for high-risk neuroblastoma (HR-NBL1/SIOPEN): an international, randomised, multi-arm, open-label, phase 3 trial. Lancet Oncol. 2017;18(4):500-14. https://doi.org/10.1016/S1470-2045(17)30070-0.

14. Simon T, Längler A, Harnischmacher U, Frühwald MC, Jorch N, Claviez A, et al. Topotecan, cyclophosphamide, and etoposide (TCE) in the treatment of high-risk neuroblastoma. Results of a phase-II trial. J Cancer Res Clin Oncol. 2007;133(9):653-61. https://doi.org/10.1007/s00432-007-0216-y.

15. Yu AL, Gilman AL, Ozkaynak MF, London WB, Kreissman SG, Chen HX, et al. Anti-GD2 antibody with GM-CSF, interleukin-2, and isotretinoin for neuroblastoma. N Engl J Med. 2010;363(14):1324-34. https://doi.org/10.1 056/NEJMoa0911123.

16. Patel YC. Somatostatin and its receptor family. Front Neuroendocrinol. 1999; 20(3):157-98. https://doi.org/10.1006/frne.1999.0183.

17. Georgantzi K, Tsolakis AV, Stridsberg M, Jakobson $\AA$, Christofferson R, Janson ET. Differentiated expression of somatostatin receptor subtypes in experimental models and clinical neuroblastoma. Pediatr Blood Cancer. 2011;56(4):584-9. https://doi.org/10.1002/pbc.22913.

18. Watanabe N, Nakanishi Y, Kinukawa N, Ohni S, Obana Y, Nakazawa A, et al. Expressions of somatostatin receptor subtypes (SSTR-1, 2, 3, 4 and 5) in neuroblastic tumors; special reference to clinicopathological correlations with international neuroblastoma pathology classification and outcomes. Acta Histochem Cytochem. 2014:14024.

19. Alexander N, Marrano P, Thorner P, Naranjo A, Van Ryn C, Martinez D, et al. Prevalence and clinical correlations of somatostatin receptor-2 (SSTR2) expression in neuroblastoma. J Pediatr Hematol Oncol. 2019;41(3):222-7. https://doi.org/10.1097/MPH.0000000000001326.

20. Kong G, Hofman MS, Murray WK, Wilson S, Wood P, Downie P, et al. Initial experience with gallium-68 DOTA-octreotate PET/CT and peptide receptor radionuclide therapy for pediatric patients with refractory metastatic neuroblastoma. J Pediatr Hematol Oncol. 2016;38(2):87-96. https://doi.org/1 0.1097/MPH.0000000000000411.

21. Albers AR, O'Dorisio MS, Balster DA, Caprara M, Gosh P, Chen F, et al. Somatostatin receptor gene expression in neuroblastoma. Regul Pept. 2000; 88(1-3):61-73. https://doi.org/10.1016/S0167-0115(99)00121-4.

22. Provost C, Prignon A, Cazes A, Combaret V, Delattre O, Janoueix-Lerosey I, et al. 68Ga-DOTATOC and FDG PET imaging of preclinical neuroblastoma models. Anticancer Res. 2016;36(9):4459-66. https://doi.org/10.21873/antica nres.10990.

23. Reubi JC, Schär J-C, Waser B, Wenger S, Heppeler A, Schmitt JS, et al. Affinity profiles for human somatostatin receptor subtypes SST1-SST5 of somatostatin radiotracers selected for scintigraphic and radiotherapeutic use. Eur J Nucl Med. 2000;27(3):273-82. https://doi.org/10.1007/s002 590050034.

24. Gains JE, Moroz V, Aldridge MD, Wan S, Wheatley K, Laidler J, et al. A phase Ila trial of molecular radiotherapy with 177-lutetium DOTATATE in children with primary refractory or relapsed high-risk neuroblastoma. Eur J Nucl Med Mol Imaging. 2020;47:1-10.

25. Schneider JR, Shatzkes DR, Scharf SC, Tham TM, Kulason KO, Buteau F-A et al. Neuroradiological and neuropathological changes after $177 \mathrm{Lu}$ - 
Octreotate peptide receptor radionuclide therapy of refractory esthesioneuroblastoma. Operat Neurosurg. 2018;15(6):100-9. https://doi. org/10.1093/ons/opy028.

26. Fransson S, Hansson M, Ruuth K, Djos A, Berbegall A, Javanmardi N, et al. Intragenic anaplastic lymphoma kinase (ALK) rearrangements: translocations as a novel mechanism of ALK activation in neuroblastoma tumors. Genes Chromosomes Cancer. 2015;54(2):99-109. https://doi.org/10.1002/gcc.22223.

27. Cazes A, Louis-Brennetot C, Mazot P, Dingli F, Lombard B, Boeva V, et al. Characterization of rearrangements involving the ALK gene reveals a novel truncated form associated with tumor aggressiveness in neuroblastoma. Cancer Res. 2013;73(1):195-204. https://doi.org/10.1158/0008-5472.CA $\mathrm{N}-12-1242$.

28. Guan J, Tucker E, Wan H, Chand D, Danielson L, Ruuth K, et al. The ALK inhibitor PF-06463922 is effective as a single agent in neuroblastoma driven by expression of ALK and MYCN. Dis Model Mech. 2016;9(9):941-52. https:// doi.org/10.1242/dmm.024448.

29. Schönherr C, Ruuth K, Kamaraj S, Wang C-L, Yang H-L, Combaret V, et al. Anaplastic lymphoma kinase (ALK) regulates initiation of transcription of MYCN in neuroblastoma cells. Oncogene. 2012;31(50):5193-200. https://doi. org/10.1038/onc.2012.12

30. Schleiermacher G, Janoueix-Lerosey I, Combaret V, Derré J, Couturier J, Aurias A, et al. Combined 24-color karyotyping and comparative genomic hybridization analysis indicates predominant rearrangements of early replicating chromosome regions in neuroblastoma. Cancer Genet Cytogenet. 2003;141(1):32-42. https://doi.org/10.1016/50165-4608(02 )00644-1.

31. Schleiermacher G, Bourdeaut F, Combaret V, Picrron G, Raynal V, Aurias A, et al. Stepwise occurrence of a complex unbalanced translocation in neuroblastoma leading to insertion of a telomere sequence and late chromosome 17q gain. Oncogene. 2005;24(20):3377-84. https://doi.org/10.1 038/sj.onc.1208486.

32. Tumilowicz JJ, Nichols WW, Cholon JJ, Greene AE. Definition of a continuous human cell line derived from neuroblastoma. Cancer Res. 1970; 30(8):2110-8.

33. Bolch WE, Eckerman KF, Sgouros G, Thomas SR. MIRD pamphlet no. 21: a generalized schema for radiopharmaceutical dosimetry - standardization of nomenclature. J Nucl Med. 2009;50(3):477-84. https://doi.org/10.2967/ jnumed.108.056036.

34. Eckerman K, Endo A. ICRP Publication 107. Nuclear decay data for dosimetric calculations. Ann ICRP. 2008;38(3):7.

35. Dalmo J, Spetz J, Montelius M, Langen B, Arvidsson Y, Johansson $H_{\text {, et al. }}$ Priming increases the anti-tumor effect and therapeutic window of $177 \mathrm{Lu}$ octreotate in nude mice bearing human small intestine neuroendocrine tumor GOT1. EJNMMI Res. 2017;7(1):6. https://doi.org/10.1186/s13550-0160247-y.

36. Dalmo J. Therapy of neuroendocrine tumors with 177Lu-octreotate human tumor cell types and models and optimization of treatment Gothenburg: University of Gothenburg; 2014.

37. Schmitt A, Bernhardt P, Nilsson O, Ahlman H, Kölby L, Schmitt J, et al. Biodistribution and dosimetry of 177Lu-labeled [DOTA0, Tyr3] octreotate in male nude mice with human small cell lung cancer. Cancer Biother Radiopharm. 2003;18(4):593-9. https://doi.org/10.1089/108497803322287682.

38. Kölby L, Bernhardt P, Johanson V, Schmitt A, Ahlman H, Forssell-Aronsson E, et al. Successful receptor-mediated radiation therapy of xenografted human midgut carcinoid tumour. Br J Cancer. 2005;93(10):1144-51. https://doi.org/1 0.1038/sj.bjc.6602845.

39. Spetz J, Langen B, Rudqvist N, Parris TZ, Helou K, Nilsson O, et al. Hedgehog inhibitor sonidegib potentiates 177 Lu-octreotate therapy of GOT1 human small intestine neuroendocrine tumors in nude mice. BMC Cancer. 2017; 17(1):528. https://doi.org/10.1186/s12885-017-3524-x.

40. Spetz J, Langen B, Rudqvist N-P, Parris TZ, Shubbar E, Dalmo J, et al. Transcriptional effects of 177 Lu-octreotate therapy using a priming treatment schedule on GOT1 tumor in nude mice. EJNMMI Res. 2019;9(1):28. https://doi.org/10.1186/s13550-019-0500-2.

41. Spetz J, Rudqvist N, Langen B, Parris TZ, Dalmo J, Schüler E, et al. Timedependent transcriptional response of GOT1 human small intestine neuroendocrine tumor after 177Lu [Lu]-octreotate therapy. Nucl Med Biol. 2018;60:11-8. https://doi.org/10.1016/j.nucmedbio.2018.01.006.

42. Strosberg J, El-Haddad G, Wolin E, Hendifar A, Yao J, Chasen B, et al. Phase 3 trial of 177Lu-Dotatate for midgut neuroendocrine tumors. N Engl J Med. 2017;376(2):125-35. https://doi.org/10.1056/NEJMoa1607427.
43. De Araújo E, Caldeira Filho J, Nagamati L, Muramoto E, Colturato M, Couto $R$, et al. A comparative study of 131 and 177 Lu labeled somatostatin analogues for therapy of neuroendocrine tumours. Appl Radiat Isot. 2009; 67(2):227-33. https://doi.org/10.1016/j.apradiso.2008.09.009.

44. Lewis JS, Wang M, Laforest R, Wang F, Erion JL, Bugaj JE, et al. Toxicity and dosimetry of 177Lu-DOTA-Y3-octreotate in a rat model. Int J Cancer. 2001; 94(6):873-7. https://doi.org/10.1002/ijc.1540.

45. de Jong M, Breeman WA, Bernard BF, Bakker WH, Schaar M, van Gameren A, et al. [177Lu-DOTA0, Tyr3] octreotate for somatostatin receptor-targeted radionuclide therapy. Int J Cancer. 2001;92(5):628-33. https://doi.org/10.1 002/1097-0215(20010601)92:5<628::AID-IJC1244>3.0.CO;2-L.

46. Dalmo J, Rudqvist N, Spetz J, Laverman P, Nilsson O, Ahlman H, et al. Biodistribution of 177Lu-octreotate and 111/n-minigastrin in female nude mice transplanted with human medullary thyroid carcinoma GOT2. Oncol Rep. 2012;27(1):174-81. https://doi.org/10.3892/or.2011.1494.

47. Waser B, Tamma M-L, Cescato R, Maecke HR, Reubi JC. Highly efficient in vivo agonist-induced internalization of sst2 receptors in somatostatin target tissues. J Nucl Med. 2009;50(6):936-41. https:/doi.org/10.2967/jnumed.108.061457.

48. Bernhardt P, Kölby L, Johanson V, Nilsson O, Ahlman H, Forssell-Aronsson E. Biodistribution of 111 in-DTPA-D-Phe1-octreotide in tumor-bearing nude mice: influence of amount injected and route of administration. Nucl Med Biol. 2003;30(3):253-60. https://doi.org/10.1016/50969-8051(02)00417-1.

49. Zhang L, Vines DC, Scollard DA, McKee T, Komal T, Ganguly M, et al. Correlation of somatostatin receptor-2 expression with Gallium-68-DOTATATE uptake in neuroblastoma xenograft models. Contrast Media Mol Imaging. 2017;2017:1-10. https://doi.org/10.1155/2017/9481276.

50. Van den Eynden J, Umapathy G, Ashouri A, Cervantes-Madrid D, Szydzik J, Ruuth $\mathrm{K}$, et al. Phosphoproteome and gene expression profiling of ALK inhibition in neuroblastoma cell lines reveals conserved oncogenic pathways. Sci Signal. 2018;11:557.

51. Borenäs M, Umapathy G, Lai WY, Lind DE, Witek B, Guan J, et al. ALK ligand ALKAL2 potentiates MYCN-driven neuroblastoma in the absence of ALK mutation. EMBO J. 2021;40(3):e105784. https://doi.org/10.15252/embj.20201 05784.

52. Schüler E, Österlund A, Forssell-Aronsson E. The amount of injected 177Luoctreotate strongly influences biodistribution and dosimetry in C57BL/6N mice. Acta Oncol. 2016;55(1):68-76. https://doi.org/10.3109/0284186X.2015.1 027001

53. Bates $\mathrm{CM}$, Kegg H, Grady S. Expression of somatostatin receptors 1 and 2 in the adult mouse kidney. Regul Pept. 2004;119(1-2):11-20. https://doi.org/1 0.1016/j.regpep.2003.12.015,

54. Bates CM, Kegg H, Petrevski C, Grady S. Expression of somatostatin receptors 3, 4, and 5 in mouse kidney proximal tubules. Kidney Int. 2003; 63(1):53-63. https://doi.org/10.1046/j.1523-1755.2003.00716.x.

55. Borie R, Fabre A, Prost F, Marchal-Somme J, Lebtahi R, Marchand-Adam S, et al. Activation of somatostatin receptors attenuates pulmonary fibrosis. Thorax. 2008;63(3):251-8. https://doi.org/10.1136/thx.2007.078006.

56. Formenti SC, Demaria S. Combining radiotherapy and cancer immunotherapy: a paradigm shift. JNCI. 2013;105(4):256-65. https://doi.org/1 0.1093/jnci/djs629.

57. Dalmo J, Rudqvist N, Spetz J, Laverman P, Nilsson O, Ahlman H, et al. Biodistribution of 177Lu-octreotate and 111/n-minigastrin in female nude mice transplanted with human medullary thyroid carcinoma GOT2. Oncol Rep. 2012;27(1):174-81. https://doi.org/10.3892/or.2011.1494.

\section{Publisher's Note}

Springer Nature remains neutral with regard to jurisdictional claims in published maps and institutional affiliations. 